\title{
UPDATING AND
}

ENHANCEMENT OF THE

BIMSTEC TRANSPORT

INFRASTRUCTURE

AND LOGISTICS STUDY

Final Report

JULY 2018 



\section{UPDATING AND \\ ENHANCEMENT OF THE \\ BIMSTEC TRANSPORT \\ INFRASTRUCTURE \\ AND LOGISTICS STUDY}

Final Report

JULY 2018 
(c) 2018 Asian Development Bank

6 ADB Avenue, Mandaluyong City, 1550 Metro Manila, Philippines

Tel +632632 4444; Fax +6326362444

www.adb.org

Some rights reserved. Published in 2018.

ISBN 978-92-9261-168-2 (print), 978-92-9261-169-9 (electronic)

Publication Stock No. RPT157680-2

DOI: http://dx.doi.org/10.22617/RPT157680-2

The views expressed in this publication are those of the authors and do not necessarily reflect the views and policies of the Asian Development Bank (ADB) or its Board of Governors or the governments they represent.

ADB does not guarantee the accuracy of the data included in this publication and accepts no responsibility for any consequence of their use. The mention of specific companies or products of manufacturers does not imply that they are endorsed or recommended by ADB in preference to others of a similar nature that are not mentioned.

By making any designation of or reference to a particular territory or geographic area, or by using the term "country" in this document, ADB does not intend to make any judgments as to the legal or other status of any territory or area.

This work is available under the Creative Commons Attribution 3.0 IGO license (CC BY 3.0 IGO)

https://creativecommons.org/licenses/by/3.0/igo/. By using the content of this publication, you agree to be bound by the terms of this license. For attribution, translations, adaptations, and permissions, please read the provisions and terms of use at https://www.adb.org/terms-use\#openaccess.

This CC license does not apply to non-ADB copyright materials in this publication. If the material is attributed to another source, please contact the copyright owner or publisher of that source for permission to reproduce it. $\mathrm{ADB}$ cannot be held liable for any claims that arise as a result of your use of the material.

Please contact pubsmarketing@adb.org if you have questions or comments with respect to content, or if you wish to obtain copyright permission for your intended use that does not fall within these terms, or for permission to use the ADB logo.

Notes:

In this publication, "\$” refers to United States dollars.

Corrigenda to ADB publications may be found at http://www.adb.org/publications/corrigenda. 


\section{Contents}

Tables and Map iv

Abbreviations $\quad \mathrm{V}$

$\begin{array}{lr}\text { Introduction } & 1\end{array}$

Assessment of Existing BIMSTEC Transport Infrastructure

and Logistics Study Policies and Strategies 3

Recommended BTILS Policies and Strategies 2014-2020

Proposed BIMSTEC Priority Infrastructure Projects 2014-2020 12

$\begin{array}{ll}\text { Implementation Indicators } & 17\end{array}$

BIMSTEC Transport Infrastructure and Logistics Plan 2014-2020 21

$\begin{array}{ll}\text { Monitoring Framework } & 27\end{array}$

Institutional Framework for BTILS Implementation $\quad 28$

$\begin{array}{ll}\text { Potential BTILS Development Theme } & 30\end{array}$

\section{Appendixes}

1 BIMSTEC Phase I Long List of Transport Infrastructure Projects and Other Relevant Ongoing Projects $\quad 33$

2 Sample Monitoring Framework $\quad 38$ 


\section{Tables and Map}

\section{Tables}

1 Proposed Short List of BIMSTEC Priority Projects, 2014-2020 15

2 Roads: Policy and Strategy Linkages of Priority Projects 17

3 Road Transport: Policy and Strategy Linkages of Priority Projects 18

$4 \quad$ Rail: Policy and Strategy Linkages of Priority Projects 19

5 Maritime: Policy and Strategy Linkages of Priority Projects 19

6 Aviation: Policy and Strategy Linkages of Priority Projects 20

7 Trade Facilitation: Policy and Strategy Linkages of Priority Projects 20

$8 \quad$ BIMSTEC Transport Infrastructure and Logistics Action Plan, 2014-2020 23

A1.1 Road Projects 33

$\begin{array}{lll}\text { A1.2 Railway Projects } & 35\end{array}$

A1.3 Maritime Projects $\quad 35$

A1.4 Inland Waterway Projects 36

A1.5 Aviation Projects 36

$\begin{array}{lll}\text { A1.6 Trade Facilitation Projects } & 37\end{array}$

Map

Key BIMSTEC Trade Routes 


\title{
Abbreviations
}

\author{
ADB - - Asian Development Bank \\ BIMSTEC - Bay of Bengal Initiative for Multi-Sectoral Technical \\ and Economic Cooperation \\ BTILS - BIMSTEC Transport Infrastructure and Logistics Study \\ ICD _ - inland clearance depot \\ ICP - - integrated check post \\ ICT - information and communication technology \\ LCC - low-cost carrier \\ $\mathrm{NH} \quad-\quad$ National Highway \\ SAARC - South Asian Association for Regional Cooperation \\ SASEC - South Asia Subregional Economic Cooperation
}





\section{Introduction}

The Bay of Bengal Initiative for Multi-Sectoral Technical and Economic Cooperation (BIMSTEC) was established as an interregional grouping in June 1997 to promote free trade within the region, increase cross-border investment and tourism, and promote technical cooperation. Its seven-country membership comprises Bangladesh, Bhutan, India, Myanmar, Nepal, Sri Lanka, and Thailand. Since its inception in 2014, the BIMSTEC Secretariat has been responsible for the overall coordination and monitoring of activities in place of the BIMSTEC Working Group in Bangkok, Thailand, which was the only established mechanism in the absence of the Secretariat.

The BIMSTEC Transport Infrastructure and Logistics Study (BTILS) was an outgrowth of demand stated at the 51st meeting of the BIMSTEC Working Group held in Bangkok, Thailand, in July 2005. The resulting BTILS project was agreed and commissioned in February 2007, with commencement in April 2007. The study was completed with Asian Development Bank (ADB) funding in November 2007, and the 12th BIMSTEC Ministerial Meeting in December 2009 endorsed the final report and its recommendations.

The BIMSTEC Working Group recognized in March 2011 that since the BTILS had been undertaken in 2007 there had been significant changes, both in relation to global and intra-regional trade and in the respective national and regional transport environments. The working group requested ADB to conduct an update and enhancement of the BTILS reflecting these changes and extending the planning time frame forward to 2020 , including assessing the future effect of the various trade-related initiatives impacting the region.

The overall study was expected to generate four key outputs:

- a profile of the transport and logistics environment in the Member States, focusing on international connectivity, both among the BIMSTEC Member States and their access to external markets (Phase I);

- recommendations on future BIMSTEC policies and strategies designed to enhance connectivity and promote the development of intra-BIMSTEC trade (Phase II);

- identification of relevant "hard" and "soft" infrastructure projects whose realization would enhance BIMSTEC connectivity and trade (Phases I and II); and

- recommendations on an effective institutional mechanism to monitor and facilitate the implementation of the agreed BIMSTEC policies, strategies, and priority projects (Phase II). 
The study has consisted of three distinct phases, each one ending with a workshop attended by the relevant BIMSTEC representatives from each of the Member States:

- Inception Phase May 2013,

- Phasel June-December 2013, and

- Phase II January-May 2014.

Phase I of the project commenced in early June 2013. The first objective was to update the original BTILS Interim Report based on the inclusion of developments that had occurred in the intervening period (2007-2013), and thus reflect the current situation of each transport mode in the Member States. The second objective was to identify relevant national transport and logistics programs that were designed to develop the region's transport environment, in the form of the "hard" and "soft" infrastructure initiatives planned for implementation between 2014 and 2020, or at least up to the respective limits of existing national plans. The third objective was to highlight potential projects post-2020 that could have longer-term implications in relation to future BIMSTEC interconnectivity.

The Phase I report was structured and presented in a manner that allowed it to be used as a comprehensive regional transport "database" from which updated BIMSTEC policies and strategies could be developed. It reflected the changing needs of the regional transport and logistics environment, identifying key projects in pursuing the goal of enhanced regional connectivity and the promotion of intra-regional trade. The report, in addition to its comprehensive database function, represented a transparent audit trail to the recommendations contained in the Phase II report. The draft Phase I report was presented and endorsed at the Phase I workshop held in Mae Sot, Thailand, in March 2014.

The Phase II report was designed to provide (i) proposals on future policies and strategies; (ii) identification of BIMSTEC priority projects; (iii) a monitoring framework for the implementation of the policies and strategies; (iv) an action plan; and ( $v$ ) an institutional structure to assist in taking the study outputs forward. The draft Phase II report was presented and endorsed at the Phase II workshop held in Dhaka, Bangladesh, in May 2014. In effect, the workshop participants discussed the contents of the report, and the resulting agreement on its contents translated the report's proposals into recommendations to be forwarded to the appropriate BIMSTEC authorities for later endorsement. This final report concentrates on the results of the Phase II report, as these represent the core outputs of the study. A final workshop was held in Delhi, India, in July 2014 to approve the contents of the draft final report. During the Fifteenth BIMSTEC Ministerial Meeting held in Kathmandu, Nepal, on 11 August 2017, the Updating and Enhancement of the BTILS Final Report was approved. 


\section{Assessment of Existing BIMSTEC Transport Infrastructure and Logistics Study Policies and Strategies}

One of the primary objectives of the Updating and Enhancement of the BIMSTEC Transport Infrastructure and Logistics Study (BTILS II) was to ensure that the existing policies and strategies remain relevant to the present and future regional connectivity needs. The initial BTILS in 2007 was the first time BIMSTEC as an economic cooperation organization had developed such policies and strategies for a particular sector. Therefore, it was somewhat experimental in nature, using the inputs of the BIMSTEC Technical Advisors Committee that had been formed for the original BTILS study.

It was recognized there was a need to initially review these existing BTILS policies and strategies to identify what progress had been achieved in their implementation. The assessment not only highlighted the successes to date, but also identified where implementation had been delayed or where changes in the transport environment have made the proposed policy or strategy either unrealistic or not applicable. It was appreciated that the success or otherwise of the policies and strategies was predominantly the result of the implementation of national programs, plus some regional initiatives being supported by development partners. For a variety of reasons, BIMSTEC has not yet been able to fulfill its remit as an acknowledged regional pressure group or lobbyist in the development of regional transport cooperation between the Member States. Thus, it is unlikely that BIMSTEC was the reason behind either the achievements or lack of progress in executing the existing policies and strategies. Nonetheless, as BIMSTEC develops in 2014 with its own secretariat, it will increasingly be in a position to influence and promote sector development to the benefit of its combined membership. To accomplish this will require transport and trade facilitation policies and strategies that are relevant, realizable, and measurable.

A detailed assessment of each of the existing policies and strategies was undertaken. The overall conclusions were broadly as follows:

- In the road sector, there has been only limited progress and some policy revisions are required;

- In the road transport sector, there has been no significant improvement and therefore some revisions would appear appropriate;

- In the rail sector, there has been some progress in Bangladesh, but some of the original policies may not be valid as reflected by the lack of progress;

- In the maritime sector, there has been progress, especially at Colombo, and most of the policies remain valid;

- In aviation, there has been significant progress, but some of the original policies may have been too operationally or technically oriented to be adopted as BIMSTEC policies and strategies; 
- In trade facilitation, there has been appreciable progress and most of the original policies remain valid; and

- In logistics, there has been no progress on the specific policies and these would need revision if they are to remain valid.

\section{Recommended BTILS Policies and Strategies 2014-2020}

The development of policies and strategies as part of the original BTILS program was intended to establish BIMSTEC's position as a development body with respect to the regional transport environment at that time, sector by sector, and to indicate how it would expect to see the sectors evolve to the benefit of BIMSTEC's overall regional development remit. With the major changes in the transport environment since then, there is a need to recommend updated policies and strategies that not only reflect the nature of that market evolution but can be supported by the potential changes within BIMSTEC's institutional structure and its expected growing influence as a key regional development forum. Changes in approach are required to ensure

- a higher level of implementation of the policies and strategies during the period 2014-2020, in order to be able to publicly demonstrate BIMSTEC's success in influencing positive change in the various modal sectors;

- greater progress in implementation of the agreed policies and strategies, thus demonstrating a sustained enhancement of the region's transport environment toward meeting BIMSTEC's overall published aims and purposes; and

- minimization or elimination of policies and strategies that may be particularly difficult to realize, and which potentially could create a negative image of BIMSTEC's ability to influence change.

A key issue emanating from the policy and strategy assessment was the difficulty in measuring achievements in relation to the existing policies and strategies, because there were no specific indicators linked to implementation. This caveat suggested that when developing the new policies and strategies, relevant indicators should be included to enable progress to be measured in the future. This will assist BIMSTEC in publicizing its regional cooperation achievements by enabling it to demonstrate the organization's ability to deliver preset targets and to focus its influence on resolving strategies that may be failing to perform as anticipated.

The policies and, to a certain extent, strategies will always tend to be generic, especially when attempting to maximize the inclusivity of seven Member States that differ appreciably in, among others, size, level of development, cultures, languages, and economies. This very diversity, which is emphasized by BIMSTEC as providing its regional uniqueness, inevitably results in developing policies and strategies in a manner intended to maximize the commonality of interests. The proposed indicators could be used to provide the necessary specificity to confirm the relevance of that particular policy or strategy in relation to the achievement of BIMSTEC's aims, as well as the role of individual Member States. 
The logical framework applied in developing the updated policies and strategies was based on the following:

- issues-identification of key difficulties in the regional transport and trade facilitation environment highlighted in Phase I of the study that should be addressed by specific policies;

- policies-statements of intent designed to guide actions toward the achievement of BIMSTEC's overall aims and purposes;

- $\quad$ strategies - approaches to be adopted in implementing the agreed policies; and

- $\quad$ indicators-developments that represent a manifestation of a particular strategy and can be used to measure progress in its implementation.

This structured approach was based on the need to have a transparent interrelationship between the proposed sector policies and BIMSTEC's core aims and purposes, as defined in the Bangkok Declaration, and to link the strategies directly back to the relevant policies. Another concern emanating from the assessment was the overall number of policies and strategies. It was considered unlikely that BIMSTEC would be in a position to influence and/or monitor such a large number of policies and strategies concurrently, even with the proposed secretariat and any agreed technical support. In addition, the more policies and strategies adopted, the greater the potential for dilution of focus. It was, therefore, decided to adopt a smaller number of policies and strategies to concentrate on and monitor, especially as BIMSTEC has 13 other priority sectors.

In the Phase II report, the key issues in each of the transport sectors were summarized and the resulting areas where BIMSTEC policies and strategies may be needed were identified. Each of these areas was then discussed to provide an audit trail to the formulation of the policies and strategies. This condensed final report summarizes the issues identified for each transport sector, together with the resulting recommended policies and strategies.

\section{Road Policies and Strategies}

Roads represent the dominant transport infrastructure used in all of the BIMSTEC Member States. They not only represent the primary means of domestic connectivity, but are also the main conduit for the movement of intra-BIMSTEC trade, either directly through land borders or via their connectivity to the seaports. The profile of the road situation in the Phase I report highlighted the major variations in road density and connectivity between the Member States. While all countries are members of the Asian Highway initiative, only India and Thailand at this stage have major Asian Highway Class I highway networks, though such highways in the northeastern states of India are still under development. Bangladesh and Sri Lanka have plans to develop Class I networks, but Bhutan, Myanmar, and Nepal are expected to be mainly reliant on Class II and Class III roads in the policy period, especially in relation to connectivity with their neighbors, due to the difficult mountainous terrain.

Based on the current situation described in the Phase I report and the assessment of existing policies and strategies, the key residual issues needing to be addressed were identified as follows: 
- $\quad$ upgrading of border linkages, including improving access to the maritime borders (ports);

- enhancement of the arterial road links carrying significant volumes of intraBIMSTEC trade; and

- coordination in the scheduling of road programs to assist in enhancing connectivity among the Member States.

The recommended policies and strategies designed to address these specific issues are as follows:

\section{Upgrading of Border Roads}

Policy: Border roads between BIMSTEC Member States should be upgraded consistent with the existing and projected future volumes of traffic expected to use that border connection, thus helping to promote increased intra-BIMSTEC trade.

Strategy: BIMSTEC will encourage Member States to include and prioritize projects to upgrade access roads to the main BIMSTEC border crossings within their national road development plans, as well as promote such investments in relevant development forums.

\section{Upgrading of Port Access Roads}

Policy: Road connectivity at the main BIMSTEC ports should be enhanced between the port gate and the connecting road networks to eliminate congestion on port access roads, thus helping to reduce transaction costs associated with trade, including for intra-BIMSTEC traffic.

Strategy: BIMSTEC will encourage Member States to include the upgrading or construction of dedicated port access roads in their national road development plans in situations where there is congestion on the existing access roads or where new ports are being developed.

\section{Enhancement of Arterial Links to Borders and Ports}

Policy: Road linkages between the BIMSTEC concentrations of trade supply and demand and the land and sea borders should be accorded high priority in national road transport plans, thus expediting intra-BIMSTEC trade movements and reducing transaction costs.

Strategy: BIMSTEC will encourage Member States to prioritize road developments along the key national arterial routes that represent the region's main existing and potential trade corridors while also allowing landlocked countries access to transit countries' road network for transport and transit of cargo to-and-from the seaports.

\section{Coordination of Road Programs}

Policy: For BIMSTEC to become more physically integrated, it is important that Member States coordinate their road planning to enhance the region's connectivity as part of their national planning mechanisms, thus supporting joint efforts to develop complementary road planning. 
Strategy: BIMSTEC will encourage Member States to exchange information on their national road development programs and establish a mechanism for the effective exchange of relevant road planning data to facilitate future coordination of road investments.

\section{Road Transport Policies and Strategies}

International transport in the BIMSTEC region consists predominantly of domestic transport operations that interface at, or are adjacent to, the international borders. Thailand is the only BIMSTEC country with an identifiable international road transport sector, but as yet there is no negotiated agreement between Thailand and Myanmar finalized under the Greater Mekong Subregion Cross-Border Transport Agreement. Indian transporters are permitted to carry goods to and from inland Bhutan and Nepal, and Bhutanese and Nepali transporters can collect or deliver goods in India or at the Indian ports under bilateral arrangements. Foreign transporters are not permitted to enter either Bangladesh or Myanmar, other than to border transfer points. Sri Lanka, being an island, has no international road transport requirements.

The need to transfer cargo at the international borders results in higher transaction costs, particularly for the importing country. The development of through transport would improve transport efficiency and lower trade costs. The recommended policy and strategy to address this issue are as follows:

\section{Implement Through-Transport Agreements}

Policy: BIMSTEC recognizes the need to develop through-transport agreements between BIMSTEC Member States and with their neighbors in order to reduce transport costs and to facilitate and promote intra-regional trade to the overall benefit of the Member States.

Strategy: BIMSTEC will encourage Member States to develop transport access agreements with their neighbors wherever possible, based on either limited or unlimited access, and will support subregional initiatives designed to encourage such through-transport arrangements.

\section{Rail Policies and Strategies}

In the BTILS, there were five rail issues with policies and their associated strategies. While there has been some progress in capacity development in Bangladesh arising from line improvements and new rolling stock, there has been no significant progress regarding any of the other issues. Unfortunately, the reality is that rail is becoming less important to intra-BIMSTEC transport, rather than growing, and any pro-environmental factors favoring the more extensive use of rail are unlikely to appreciably change this scenario. This situation suggests the need to adopt a more cautious approach to selecting future BIMSTEC policies and strategies, as the chances of successful implementation appear less certain.

A key aspect in policy selection was that each of the rail networks operates independently. There is limited evidence to suggest commonality of issues with respect to international services, and therefore development of a regional dimension to rail infrastructure is difficult. 
One approach in identifying common themes has been to examine the "long list" of projects identified in the Phase I report (Appendix 1), which indicates the future plans of the various national rail organizations. Two areas of commonality are rail connectivity with the landlocked countries and to the key seaports. The recommended policies and strategies designed to address these specific issues are as follows:

\section{Rail Connectivity to Landlocked Countries}

Policy: BIMSTEC recognizes the specific connectivity requirements of the landlocked Member States and supports their need for modal alternatives, where viable, in order to promote intraBIMSTEC trade and social development along the borders of the respective Member States.

Strategy: BIMSTEC will encourage the development of rail links between India and the landlocked Member States of Bhutan and Nepal.

\section{Enhanced Rail Connectivity between Ports and Their Hinterland}

Policy: BIMSTEC Member States require enhanced rail accessibility to their main ports to support the growth in intra-regional trade and to encourage economic and social development at inland locations.

Strategy: BIMSTEC will encourage Member States to prioritize rail access to new and existing ports, especially for the movement of bulk and semi-bulk cargoes and the transit of container traffic between the ports and inland clearance depots (ICDs).

\section{Maritime Policies and Strategies}

Maritime transport already plays an important role in trade in all BIMSTEC Member States directly or indirectly (in the case of the landlocked Member States). The majority of each country's international trade, except in the case of Bhutan and Nepal, is carried by sea. Indications are also that most intra-BIMSTEC trade in tonnage terms is currently carried by sea due to the combination of the physical constraints to land connectivity, the lower unit costs of maritime transport compared with that of long-distance road transport, the types of goods being traded, and the concentration of supply and demand along seaboards, among others. Even in trade between India and the landlocked Member States, this traffic often includes significant reexports of goods that originally came through the Indian ports. This situation clearly indicates that maritime transport, and in particular seaports, will have an important role in the future transport development of the BIMSTEC region.

An analysis of the current port environment in the Phase I report suggested there were two residual key areas of concern that were common to several countries and therefore could be considered as having a regional dimension: (i) access to deeper water to enable larger vessels to call, and (ii) the container handling performance at some of the key ports in the Bay of Bengal. The recommended policies and strategies designed to address these specific issues are as follows: 


\section{Development of Deeper Water Ports}

Policy: BIMSTEC recognizes the need for deeper water ports in the northern parts of the Bay of Bengal and the Andaman Sea to accommodate larger container feeder vessels, in order to facilitate trade and promote economic development in the vicinity of port complexes.

Strategy: BIMSTEC will actively promote the development of new ports in the Member States and the expansion of existing harbor infrastructure designed to increase the capacity of the region's ports to handle the anticipated growth in container traffic.

\section{Container Handling at Bay of Bengal Ports}

Policy: BIMSTEC recognizes the importance of container shipping and the need for ports to continue investing in modern container handling equipment to ensure raising terminal handling performance to help in supporting the enabling environment for rapid economic development.

Strategy: BIMSTEC will encourage the port sector to invest in additional container handling equipment, commensurate with demand and the need to raise handling performance to be compatible with global "best practice" standards.

\section{Inland Waterways Policies and Strategies}

The BTILS in 2007 did not include specific policies and strategies related to the development of inland waterway transport. There were a number of reasons for this situation, the main ones being (i) the lack of clarity in relation to firm development programs at that time; (ii) that this form of transport was only applicable to three Member States-Bangladesh, India, and Myanmar; and (iii) that the mode was principally used for domestic, rather than international, transport. Its penetration of the international sector was relatively minimal and mainly restricted to lighterage operations and the carriage of low-value products, such as aggregates and some cereals and rice. In essence, the situation remains almost unchanged. While BIMSTEC, as a promoter of regional economic development, supports all forms of transport development, at this stage the inland waterways and related development issues are not considered sufficiently encompassing of overall transport activities in the Member States to support the need for individual modal policies and strategies.

\section{Aviation Policies and Strategies}

Aviation is probably the most dynamic of the transport modes in recent years and has the highest profile internationally. This situation has, to a large extent, been driven by the rapid growth in low-cost carrier (LCC) operations and the increasing numbers of such carriers. In addition, the growing wealth of the region and improved access to flights have substantially increased overall levels of demand, even for the legacy carriers. In the context of this study, the focus has been on infrastructure-and therefore airports and their ability to handle this continued growth-rather than in relation to the carriers, who are increasingly coming from the private sector. 
The most critical issue remaining from the initial BTILS recommendations is the continued expansion of airport capacity for both passengers and freight. There are major programs for airport development in all seven Member States, and therefore it is clearly an area where BIMSTEC should have some policy. An additional issue of common interest is the development of the LCC market, where high annual growth rates have continued, despite sometimes difficult economic conditions. The recommended policies and strategies designed to address these specific issues are as follows:

\section{Expansion of Airport Capacity}

Policy: BIMSTEC supports the need to upgrade and expand airport infrastructure to meet the growing regional demand for air travel, with its ability to help promote economic development and social progress in the region.

Strategy: BIMSTEC will promote the demand-based development of airport facilities in the Member States by encouraging their prioritization in national plans and in discussions with member governments and international donor agencies.

\section{Development of Freight Services and Facilities}

Policy: BIMSTEC recognizes the need for more modern air cargo handling and equipment at the region's main airports to support the growing demand for airfreight movements arising from the region's economic development and the gradual transition towards the production of highervalue exports requiring more rapid transit.

Strategy: BIMSTEC supports the need for investment in cargo infrastructure and equipment at major airports in the Member States and will encourage prioritization of its development wherever possible.

\section{Development of Support Facilities for Low-Cost Carrier Operations}

Policy: BIMSTEC recognizes the importance of the expansion of $L C C$ operations in the region in providing increased access to international air travel among BIMSTEC Member States, thus helping to stimulate economic development and social progress in the region.

Strategy: BIMSTEC will promote the development of additional infrastructure where needed at the region's main airports to facilitate the handling of $L C C$ services, without compromising the infrastructure needed for servicing legacy carriers.

\section{Trade Facilitation Policies and Strategies}

At the time of the BTILS in 2007, the focus on trade facilitation was mainly on the development of physical infrastructure, particularly the facilities at the border crossings and any supporting inland clearance depots (ICDs). This was compatible with the overall emphasis on "hard" infrastructure at that time. However, it has become increasingly clear 
that the practices and procedures at the borders represent a critical nontariff barrier that is equal to or even more of a constraint to the efficient movement of international traffic through those facilities and are a prime cause of border congestion. The two issues of border infrastructure and practices and procedures appear intrinsically linked, because any improvements in the physical infrastructure will often generate only limited benefits unless there are corresponding enhancements in the border operations to ensure more rapid transit times through those new facilities.

An analysis of the current situation suggests the various issues addressed in the BTILS could be amalgamated to provide a significantly smaller number of more focused policies that could be more easily monitored. Regarding "hard" infrastructure, the key issues are further development of the main border posts, including any associated dry ports, and of ICDs. The "soft" infrastructure issues mainly relate to customs modernization and the ever-increasing use of information and communication technology (ICT), as well as the introduction of new approaches to automation and reductions in trade documentation. The recommended policies and strategies designed to address these specific issues are as follows:

\section{Development of Border Infrastructure}

Policy: BIMSTEC recognizes the need to develop additional infrastructure at the main land borders in the Member States to facilitate the movement of intra-BIMSTEC trade and to assist in promoting economic development in those border areas.

Strategy: BIMSTEC will encourage the prioritization of the development of border infrastructure at all of the main BIMSTEC land borders, including their inclusion in national development plans and in discussions with the relevant national authorities and international donors.

\section{Construction of Inland Clearance Depots}

Policy: BIMSTEC recognizes the need for further development of inland clearance depots to reduce the risk of increased congestion at the main seaports and to facilitate clearances, thus promoting economic development inland beyond the seaboards.

Strategy: BIMSTEC will promote the development of inland clearance depots at appropriate locations in the Member States by encouraging their inclusion in national development plans and in discussions with relevant authorities and donors.

\section{Simplification and Harmonization of Import-Export Documentation}

Policy: BIMSTEC recognizes the need for simplification and harmonization of the regional trade facilitation environment in order to promote intra-BIMSTEC trade and the resulting economic development.

Strategy: BIMSTEC will encourage Member States to review and rationalize their documentation requirements in relation to import and export clearances wherever possible and promote the development of more mutual recognition agreements between Member States. 


\section{Further Development of Automated Systems}

Policy: BIMSTEC recognizes the need for further automation in the trade facilitation environment, including implementation of more automated processing applications and the development of national single windows, in order to promote trade in the BIMSTEC Member States and to realize the economic development that such trade can generate.

Strategy: BIMSTEC will encourage the prioritization of upgrading of the existing ICT systems within national customs and help promote the establishment of national single windows with the relevant national organizations and international donors.

\section{Logistics Policies and Strategies}

A key problem has been the differing interpretations of the terminology between the institutional perception of logistics and those of the organizations actually operating within the marketplace. The transport industry considers logistics as being the management of the overall supply chain between the points of production and consumption. Given this industry definition, it is evident that logistics is likely to be dominated by the private sector, as it requires high levels of customer orientation and complex ICT support. Consequently, this subject probably lies beyond BIMSTEC's regional development remit and its influence would likely be minimal.

Conversely, the institutional understanding of "logistics" tends to be synonymous with "transport," in which case it can be argued that most of the policies and strategies described above relate to transport, and therefore directly or indirectly to enhancing logistics. It was considered there was limited value in attempting to develop particular additional policies and strategies, especially as no progress had been identified in the existing BTILS logistics policies and strategies.

\section{Proposed BIMSTEC Priority Infrastructure Projects 2014-2020}

BIMSTEC's remit on its formation in June 1997 was to promote free trade within the region, increase cross-border investment and tourism, and promote technical cooperation. In the context of the updating and enhancement of the BTILS, there is a need to not only identify policies and strategies for the transport and logistics sectors commensurate with that remit, but also to identify priority infrastructure projects which could (i) support the overall aims of BIMSTEC, (ii) operationalize the updated policies and strategies underlying BTILS, and (iii) potentially be used as a mechanism to monitor progress in the implementation of those policies and strategies.

In the Phase I report, a "long list" of infrastructure projects was prepared. This consisted of future projects identified by relevant officials in each Member State, the contents of national sector development plans, and/or the programs and plans of the various international donors. The majority of these projects are expected to be executed during 
the period 2014-2020, but in many cases, their implementation timing will be highly dependent on the availability and scheduling of funding. It was recognized that the initial long list contained few "soft" or nonphysical infrastructure projects. This was because such projects are generally not specified within national plans, or they represent components within ongoing short-term technical assistance initiatives. However, it is appreciated that there will be ongoing demand for various soft infrastructure projects, either to support the hard infrastructure programs in the form of planning studies or to assist countries in achieving international best practice in other areas, such as trade facilitation and transport facilitation. Consequently, a number of potential soft infrastructure projects were added to the initial long list for priority assessment purposes.

The study proposed the identification of a "short list" of priority hard and soft infrastructure projects that would support the aims of BIMSTEC, or alternatively that could be used to monitor the implementation of their transport policies and strategies. However, it was also recognized that this "short list" should include consideration of relevant ongoing projects impacting on trade connectivity, particularly those which had just been approved for funding or were at an early stage of implementation. Many of the identified "long list" projects will probably have a significant time lapse between their commencement and completion, and it was therefore logical to include a variety of projects that could be realized during the initial part of the policy and strategy period. The inclusion of projects that have already started can demonstrate continuity in enhancing BIMSTEC connectivity and assist in establishing a more effective monitoring mechanism. Thus, all key BIMSTECrelated ongoing transport infrastructure projects were added to the Phase I long list to ensure that all relevant infrastructure activities between 2014 and 2020 were included in the priority assessment.

A standard methodology for identification of priority projects is to screen projects using a series of selected criteria reflecting the key objectives of the particular initiative. Using this approach, each project is individually evaluated and then scored, with higher scores reflecting its positive impact in achieving the goals of a particular criterion-i.e., the higher the number scored, the greater its potential positive effect in relation to that criterion. However, it is also recognized that all criteria may not be of equal importance, so it is necessary to have a weighting index that ensures the most important criteria score more highly than the less relevant ones. The resulting criteria score multiplied by the weighting index provides a total score per project, and this can then be used to identify the likely prioritization of initiatives. The advantage of this structured methodology is that it can be adapted for use in each of the transport modes and enables priority comparisons to be undertaken between modes.

A common approach is also to limit the size of both the criteria scoring and the weighting indexes. Lower scores and multipliers are not only simpler to apply, but the application of higher numbers and multipliers tends to artificially exaggerate the differences between projects. Criteria scoring based on a scale of $1-5$ and a weighting index multiplier of 1-3 were considered sufficient to highlight those projects that best comply with the range of selected criteria, and therefore represent the priority projects. The criteria and weighting indexes were agreed by delegates at the Phase I workshop. 
In prioritizing projects, it should be noted that all of the 166 projects listed in the assessment (Appendix 1) have been identified as being important in a national context, otherwise they would not have been included in governmental or donor infrastructure development programs. In some cases, the projects are clearly identified as national priorities, but in others, they are included within general planning programs without any specific prioritization relative to each other. A further complication is that many national plans tend to be modal specific, mainly because different ministries or departments are often responsible for the various transport modes. Clearly, this situation makes prioritization within a BIMSTEC multimodal transport remit more complex. The objective of the screening process is to identify, in a structured manner, those projects whose implementation is likely to be the most beneficial to the achievement of BIMSTEC's overall remit within the transport sector-that of enhancing connectivity among the Member States, especially to promote trade with its positive impact on regional economic development.

The resulting priority projects above all relate to development of hard infrastructure, but it is recognized that soft infrastructure projects, such as prefeasibility, feasibility, and project preparation technical assistance studies linked to potential investment projects, also need to be considered. Another common type of soft infrastructure project relates to trade and transport facilitation. Such projects are particularly important to BIMSTEC as they facilitate the movement of trade between the Member States. These consist mainly of regional initiatives, such as through ADB-supported South Asia Subregional Economic Cooperation (SASEC) and Greater Mekong Subregion programs and those developed by Japan International Cooperation Agency (JICA), the World Bank, and World Customs Organization, among others. Another important area is capacity building in support of hard infrastructure development, such as training in transport planning, road engineering, transport economics, and rail management. These types of projects are designed to provide the Member States with increased technical capacities to enable them to identify, plan, design and undertake transport projects without having to rely as heavily on external technical resources.

Using a similar screening approach, the scoring differentials in soft infrastructure projects were not as great as those for hard infrastructure. This was not surprising as the majority of projects related to differing facets of trade or transport facilitation, and thus there was an element of commonality between them. The requirements for initiatives to reduce the levels of trade documentation, build capacity in customs departments, and develop national single windows suggest there may be potential for a regional, rather than solely national, approach. The other highly ranked soft projects related to the planning of developments in Myanmar. The government has initiated these planning projects, with the assistance of JICA, and the results were seen as critical in identifying national hard transport infrastructure projects, and subsequently prioritizing those projects of significance to BIMSTEC. Until these projects are completed and approved by the government, it is difficult for external parties to focus on the hard infrastructure opportunities in Myanmar. 


\section{Table 1: Proposed Short List of BIMSTEC Priority Projects, 2014-2020}

\begin{tabular}{|c|c|c|c|}
\hline Mode & Country & Project & Timescale \\
\hline Road & BAN & 4 laning Daudkandi-Chittagong highway & 2014-2015 \\
\hline Road & BAN & Construction of second Katchpur, Megna, Gomti bridges & 2014-2018 \\
\hline Road & BAN & 4 laning Benapole to Jessore & $2016-2020$ \\
\hline Road & BAN & 4 laning Jessore to Magura to Daulatdia & $2016-2020$ \\
\hline Road & BAN & Construction of the Padma bridge & $2015-2020$ \\
\hline Road & BAN & 4 laning Paturia to Nabinagar & $2016-2020$ \\
\hline Road & $\mathrm{BHU}$ & Chhukha-Damchu bypass on the Thimphu-Phuentsholing highway & 2015-2016 \\
\hline Road & IND & 4 laning Motihari-Raxaul National Highway NH 28A & 2014-2015 \\
\hline Road & IND & 4-laning NH from Dumdum to Barasat & 2014-2018 \\
\hline Road & IND & 4-laning NH from Barasat to junction State Road 1 & 2014-2018 \\
\hline Road & IND & 4-laning elevated road to Kolkata Port & 2014-2016 \\
\hline Road & IND & 4-laning access roads to Diamond Harbor & 2014-2016 \\
\hline Road & IND & 4-laning missing highway link near Siliguri NH 31D & 2014-2016 \\
\hline Road & IND & 2-4 laning NH from Imphal to Moreh & 2015-2018 \\
\hline Road & IND & Improvements in highway links in West Bengal and Bihar & 2014-2016 \\
\hline Road & IND & 4 laning Kolkata-Siliguri corridor NH 34 & $2014-2020$ \\
\hline Road & IND & 4 laning Siliguri-Guwahati NH $31 \mathrm{C}$ & 2014-2018 \\
\hline Road & IND & 4 laning Guwahati-Shillong NH 40 & 2014-2015 \\
\hline Road & MYA & New border link Mae Sot/Myawaddy & 2015-2018 \\
\hline Road & MYA & Myawaddy-Kawkareik road & 2014-2017 \\
\hline Road & MYA & Construction of Kawkareik-Eindu road & 2015-2018 \\
\hline Road & MYA & Improvement of Thilawa-East Dagon road & 2015-2017 \\
\hline Road & MYA & Yagyi-Kalewa road improvement & 2015-2017 \\
\hline Road & MYA & Bridges on Kalewa-Tamu road & 2014-2016 \\
\hline Road & NEP & Connection road between ICP and the ICD at Birgunj & 2016-2017 \\
\hline Road & NEP & Kathmandu-Terai Fast Track Road & $2016-2020$ \\
\hline Road & NEP & Nijgadh-Pathalaiya-Raxaul road upgrade & 2016-2019 \\
\hline Road & SRI & Port Access Expressway project & 2016-2019 \\
\hline Road & SRI & Extension of Colombo-Katunayake Expressway & $2015-2018$ \\
\hline Road & THA & 4 laning of the Tak-Mae Sot highway & 2014-2018 \\
\hline Road & THA & New border link Mae Sot/Myawaddy & 2015-2018 \\
\hline Road & THA & Development of the Nong Kham interchange & 2014-2018 \\
\hline Rail & BAN & Tongi-Bhairab Bazaar extra tracking & 2014-2015 \\
\hline Rail & BAN & Second bridges at Bhairab Bazaar and Titas & 2014-2016 \\
\hline Rail & BAN & 2 more lines Dhaka-Tongi and Tongi-Joydevpur & 2014-2015 \\
\hline Rail & BAN & Double tracking Laksham-Akhaura link & 2016-2019 \\
\hline Rail & BAN & Bridge parallel to Bangabandhu Bridge & $2016-2020$ \\
\hline Rail & IND & Eastern Dedicated Freight Corridor & 2014-2019 \\
\hline
\end{tabular}


Table 1 continued

\begin{tabular}{|c|c|c|c|}
\hline Mode & Country & Project & Timescale \\
\hline Rail & NEP & 5 new rail connections with India & $2014-2020$ \\
\hline Rail & THA & Chachoengsao-Klong 19-Kaeng Khoi project & 2014-2016 \\
\hline Maritime & BAN & Karnafully Container Terminal at Chittagong & 2014-2016 \\
\hline Maritime & IND & New container port at Diamond Harbor & 2014-2017 \\
\hline Maritime & IND & Elevated expressway into Chennai Port & 2014-2015 \\
\hline Maritime & IND & Additional harbor cranes at Kolkata Port & 2014 \\
\hline Maritime & MYA & New port facilities at Thilawa special economic zone & $2014-2020$ \\
\hline Maritime & SRI & Extension of East Terminal Colombo & 2014-2017 \\
\hline Maritime & SRI & Construction of West Terminal Colombo & $2018-2020$ \\
\hline Maritime & THA & Development of Phase III at Laem Chabang & $2017-2024$ \\
\hline Maritime & THA & Development of new coastal terminal at Laem Chabang & $2015-2016$ \\
\hline Maritime & THA & Development of new rail terminal at Laem Chabang & $2015-2016$ \\
\hline Aviation & BAN & Upgrading of runway at Dhaka Airport & $2015-2018$ \\
\hline Aviation & BAN & Improvement of parking aprons at Dhaka Airport & 2014 \\
\hline Aviation & $\mathrm{BHU}$ & Expansion and development of facilities at Paro Airport & 2014-2017 \\
\hline Aviation & IND & Further development of Delhi Airport & 2014-2018 \\
\hline Aviation & MYA & Upgrading of Yangon Airport & 2014-2016 \\
\hline Aviation & NEP & Major development of Kathmandu Airport & 2014-2017 \\
\hline Aviation & SRI & Phase II development of Bandaranaike International Airport, Colombo & $2015-2017$ \\
\hline Aviation & THA & Major development of Suvarnabhumi Airport at Bangkok & $2014-2020$ \\
\hline $\mathrm{TF}$ & BAN & Second rail-connected ICD in Dhaka & 2015-2018 \\
\hline TF & BAN & Developments at Benapole and Burimari & 2014-2017 \\
\hline TF & $\mathrm{BHU}$ & New ICD and access road to Pasakha Industrial Estate & 2015-2017 \\
\hline TF & $\mathrm{BHU}$ & New dry port at Phuentsholing + northern bypass & 2014-2018 \\
\hline $\mathrm{TF}$ & IND & ICP at Petrapole & 2014-2015 \\
\hline TF & MYA & Yangon/East Dagon ICD project & 2014-2016 \\
\hline TF & NEP & ICP at Birgunj & 2014-15 \\
\hline
\end{tabular}

BAN = Bangladesh, $B H U=$ Bhutan, $I C D=$ inland clearance depot, $I C P=$ integrated check post, IND = India, MYA = Myanmar, NEP = Nepal, NH = National Highway, SRI = Sri Lanka, TF = trade facilitation, $\mathrm{THA}=$ Thailand . Source: Asian Development Bank.

The assessment indicated the priority BIMSTEC soft infrastructure projects related to the following issues:

- increased customs automation through system upgrades,

- reductions in trade documentation,

- $\quad$ training of border personnel,

- development of national single windows,

- $\quad$ transport planning in Myanmar, and

- $\quad$ port and road planning in Bangladesh. 
It can be seen that, in relation to BIMSTEC soft infrastructure, the priorities should probably be issue-based, rather than concentrated on particular projects. This reflects the degree of commonality of issues in many of the countries and the particular problem of identifying soft infrastructure projects on a national basis that are beneficial to BIMSTEC with its regional remit.

\section{Implementation Indicators}

A key issue identified earlier was the absence of an indicator mechanism in the earlier BTILS. While it is recognized that BIMSTEC may not have had the institutional capacity to monitor progress at that time, there was also no suitable mechanism put in place to measure progress in implementation. Given this caveat, it was proposed to not only have fewer, more focused policies and strategies, but to link them, wherever possible, to specific projects, which when implemented could demonstrate whether that particular policy or strategy was progressing. BIMSTEC is expected to continue to have limited specialist resources available to monitor implementation and, consequently, there was a need to devise a simple monitoring mechanism capable of measuring progress by means of the undertaking and completion of the identified priority projects. The indicators for each of the policies and strategies are shown in Tables 2-7.

Table 2: Roads: Policy and Strategy Linkages of Priority Projects

\begin{tabular}{|c|c|c|c|}
\hline Issue & Policy & Strategy & Project \\
\hline $\begin{array}{l}\text { Upgrading of } \\
\text { Border Roads }\end{array}$ & $\begin{array}{l}\text { Border roads between } \\
\text { BIMSTEC Member States } \\
\text { should be upgraded consistent } \\
\text { with the existing and projected } \\
\text { future volumes of traffic } \\
\text { expected to use that border } \\
\text { connection, thus helping to } \\
\text { promote increased intra- } \\
\text { BIMSTEC trade. }\end{array}$ & $\begin{array}{l}\text { BIMSTEC will encourage } \\
\text { Member States to include } \\
\text { projects to upgrade the } \\
\text { access roads to the main } \\
\text { BIMSTEC border crossings } \\
\text { within their national } \\
\text { road development plans } \\
\text { and their prioritization, } \\
\text { as well as promote such } \\
\text { investments in relevant } \\
\text { development forums. }\end{array}$ & $\begin{array}{l}4 \text { laning Benapole to Jessore (BAN) } \\
\text { Upgrading Imphal-Moreh highway } \\
\text { (IND) } \\
4 \text { laning Motihari-Raxaul NH 28A } \\
\text { (IND) } \\
\text { Myawaddy-Kawkareik road (MYA) } \\
\text { Kawkareik-Eindu road (MYA) } \\
\text { Kalewa-Tamu road (MYA) } \\
\text { Bridges on Kalewa-Tamu road (MYA) } \\
\text { Connection of ICP at Birgunj(NEP) } \\
\text { Nijgadh-Pathalaiya-Raxaul road (NEP) } \\
\text { Upgrading of Tak-Mae Sot highway } \\
\text { (THA) }\end{array}$ \\
\hline $\begin{array}{l}\text { Upgrading Port } \\
\text { Access Roads }\end{array}$ & $\begin{array}{l}\text { Road connectivity at the } \\
\text { main BIMSTEC ports should } \\
\text { be enhanced between the } \\
\text { port gate and the connecting } \\
\text { road networks to eliminate } \\
\text { congestion on port access } \\
\text { roads, thus helping to reduce } \\
\text { transaction costs associated } \\
\text { with trade, including intra- } \\
\text { BIMSTEC traffic. }\end{array}$ & $\begin{array}{l}\text { BIMSTEC will encourage } \\
\text { Member States to } \\
\text { include the upgrading or } \\
\text { construction of dedicated } \\
\text { port access roads in their } \\
\text { national road development } \\
\text { plans in situations where } \\
\text { there is congestion on the } \\
\text { existing access roads or } \\
\text { where new ports are being } \\
\text { developed. }\end{array}$ & $\begin{array}{l}\text { Elevated accessway to Kolkata Port } \\
\text { (IND) } \\
\text { Access roads to Diamond Harbor } \\
\text { (IND) } \\
\text { Elevated access road to Chennai Port } \\
\text { (IND) } \\
\text { Upgrade Thilawa-East Dagon road } \\
\text { (MYA) } \\
\text { Port access expressway project (SRI) } \\
\text { Extension of Colombo-Katunayake } \\
\text { Expressway (SRI) } \\
\text { Nong Kham Interchange (THA) }\end{array}$ \\
\hline
\end{tabular}




\section{Table 2 continued}

\begin{tabular}{|c|c|c|c|}
\hline Issue & Policy & Strategy & Project \\
\hline $\begin{array}{l}\text { Enhancement } \\
\text { of Arterial Links } \\
\text { to Borders and } \\
\text { Ports }\end{array}$ & $\begin{array}{l}\text { Road linkages between the } \\
\text { BIMSTEC concentrations } \\
\text { of trade supply and demand } \\
\text { and the land and sea } \\
\text { borders should be accorded } \\
\text { high priority in national } \\
\text { road transport plans, thus } \\
\text { expediting intra-BIMSTEC } \\
\text { trade movements and reducing } \\
\text { transaction costs and potential } \\
\text { trade corridors. }\end{array}$ & $\begin{array}{l}\text { BIMSTEC will encourage } \\
\text { Member States to prioritize } \\
\text { road developments along } \\
\text { the key national arterial } \\
\text { routes that represent the } \\
\text { region's main existing and } \\
\text { potential trade corridors. }\end{array}$ & $\begin{array}{l}\text { Daukandi-Chittagong highway (BAN) } \\
\text { Second Katchpur, Megna, Gomti bridges } \\
\text { (BAN) } \\
\text { Construction of Padma bridge (BAN) } \\
4 \text { laning Jessore-Magura-Daulatdia } \\
\text { (BAN) } \\
4 \text { laning Paturia-Nabinagar (BAN) } \\
\text { Chhukha-Damchu bypass on Thimphu- } \\
\text { Phuentsholing highway (BHU) } \\
\text { Missing link near Siliguri NH 31D (IND) } \\
4 \text { laning Dumdum-Barasat (IND) } \\
4 \text { laning Barasat to junction State Road } \\
1 \text { (IND) } \\
4 \text { laning Kolkata-Siliguri NH } 34 \text { (IND) } \\
4 \text { laning Siliguri-Guwahati NH } 31 C \text { (IND) } \\
\text { Improvements in West Bengal and Bihar } \\
\text { (IND) } \\
4 \text { laning Guwahati-Shillong NH } 40 \\
\text { (IND) } \\
\text { Yagyi-Kalewa road (MYA) } \\
\text { Kathmandu-Terai Fast Track Road (NEP) }\end{array}$ \\
\hline $\begin{array}{l}\text { Coordination of } \\
\text { Road Programs }\end{array}$ & $\begin{array}{l}\text { For BIMSTEC to become } \\
\text { more physically integrated it is } \\
\text { important that Member States } \\
\text { coordinate their road planning } \\
\text { to enhance the region's } \\
\text { connectivity as part of their } \\
\text { national planning mechanisms, } \\
\text { thus supporting joint efforts } \\
\text { to develop complementary } \\
\text { road planning. }\end{array}$ & $\begin{array}{l}\text { BIMSTEC will encourage } \\
\text { Member States to exchange } \\
\text { information on their } \\
\text { national road development } \\
\text { programs and establish a } \\
\text { mechanism for the effective } \\
\text { exchange of relevant road } \\
\text { planning data to facilitate } \\
\text { future coordination of road } \\
\text { investments. }\end{array}$ & $\begin{array}{l}\text { Development of the Trilateral Highway } \\
\text { both within Myanmar and connection } \\
\text { in India and Thailand (IND/MYA/THA) } \\
\text { New border link Mae Sot/Myawaddy } \\
\text { (MYA and THA) }\end{array}$ \\
\hline
\end{tabular}

$\mathrm{BAN}=$ Bangladesh, $\mathrm{BHU}=$ Bhutan, $\mathrm{BIMSTEC}=$ Bay of Bengal Initiative for Multi-Sectoral Technical and Economic Cooperation, $I C P=$ integrated check point, IND = India, MYA = Myanmar, NEP = Nepal, SRI = Sri Lanka, THA = Thailand.

Source: Asian Development Bank.

\section{Table 3: Road Transport: Policy and Strategy Linkages of Priority Projects}

\begin{tabular}{|c|c|c|c|}
\hline Issue & Policy & Strategy & Project \\
\hline $\begin{array}{l}\text { Implement } \\
\text { Through- } \\
\text { Transport } \\
\text { Agreements }\end{array}$ & $\begin{array}{l}\text { BIMSTEC recognizes the } \\
\text { need to develop through- } \\
\text { transport agreements between } \\
\text { BIMSTEC Member States } \\
\text { and their neighbors in order } \\
\text { to reduce transport costs and } \\
\text { facilitate and promote intra- } \\
\text { regional trade to the overall } \\
\text { benefit of Member States. }\end{array}$ & $\begin{array}{l}\text { BIMSTEC will encourage } \\
\text { Member States to } \\
\text { develop transport access } \\
\text { agreements with their } \\
\text { neighbors wherever } \\
\text { possible, based on either } \\
\text { limited or unlimited access, } \\
\text { and will support subregional } \\
\text { initiatives designed to } \\
\text { encourage such through- } \\
\text { transport arrangements. }\end{array}$ & $\begin{array}{l}\text { Monitoring of cross-border transport } \\
\text { agreement re: arrangements between } \\
\text { Myanmar and Thailand } \\
\text { Monitoring of bilateral discussions } \\
\text { between Bangladesh and India }\end{array}$ \\
\hline
\end{tabular}

BIMSTEC = Bay of Bengal Initiative for Multi-Sectoral Technical and Economic Cooperation.

Source: Asian Development Bank. 


\section{Table 4: Rail: Policy and Strategy Linkages of Priority Projects}

\begin{tabular}{|c|c|c|c|}
\hline Issue & Policy & Strategy & Project \\
\hline $\begin{array}{l}\text { Rail Connectivity } \\
\text { to Landlocked } \\
\text { Countries }\end{array}$ & $\begin{array}{l}\text { BIMSTEC recognizes the } \\
\text { specific connectivity needs } \\
\text { of the landlocked Member } \\
\text { States and supports their need } \\
\text { for modal alternatives, where } \\
\text { viable, in order to promote } \\
\text { intra-BIMSTEC trade and } \\
\text { social development along } \\
\text { the borders of the respective } \\
\text { countries. }\end{array}$ & $\begin{array}{l}\text { BIMSTEC will encourage } \\
\text { the development of rail } \\
\text { links between India and the } \\
\text { landlocked Member States } \\
\text { of Bhutan and Nepal. }\end{array}$ & $\begin{array}{l}5 \text { new rail connections between India } \\
\text { and Nepal (NEP) }\end{array}$ \\
\hline $\begin{array}{l}\text { Enhanced Rail } \\
\text { Connectivity } \\
\text { between Ports } \\
\text { and Their } \\
\text { Hinterland }\end{array}$ & $\begin{array}{l}\text { BIMSTEC Member States } \\
\text { require enhanced rail } \\
\text { accessibility to their main } \\
\text { ports to support the growth } \\
\text { in intra-regional trade and } \\
\text { to encourage economic and } \\
\text { social development at inland } \\
\text { locations. }\end{array}$ & $\begin{array}{l}\text { BIMSTEC will encourage } \\
\text { Member States to prioritize } \\
\text { rail access to new and } \\
\text { existing ports, especially } \\
\text { for the movement of bulk } \\
\text { and semi-bulk cargoes and } \\
\text { the movement of container } \\
\text { traffic between the ports } \\
\text { and inland clearance } \\
\text { depots. }\end{array}$ & $\begin{array}{l}\text { Tongi-Bhairab Bazaar extra tracking } \\
\text { (BAN) } \\
\text { Second bridges at Bhairab Bazaar and } \\
\text { Titas (BAN) } \\
\text { Two extra lines Dhaka-Tongi and } \\
\text { Joydevpur (BAN) } \\
\text { Double tracking Laksham-Akhaura (BAN) } \\
\text { Bridge parallel to Bangabandhu Bridge } \\
\text { (BAN) } \\
\text { Eastern Dedicated Freight Corridor (IND) } \\
\text { Chachoengsao-Klong 19-Kaeng Khoi } \\
\text { project (THA) }\end{array}$ \\
\hline
\end{tabular}

BAN $=$ Bangladesh, BIMSTEC $=$ Bay of Bengal Initiative for Multi-Sectoral Technical and Economic Cooperation, IND = India, NEP $=$ Nepal, THA $=$ Thailand.

Source: Asian Development Bank.

Table 5: Maritime: Policy and Strategy Linkages of Priority Projects

\begin{tabular}{|c|c|c|c|}
\hline Issue & Policy & Strategy & Project \\
\hline $\begin{array}{l}\text { Development of } \\
\text { Deeper Water } \\
\text { Ports }\end{array}$ & $\begin{array}{l}\text { BIMSTEC recognizes the } \\
\text { need for deeper water ports } \\
\text { in the north of the Bay of } \\
\text { Bengal and Andaman Sea to } \\
\text { accommodate larger container } \\
\text { feeder vessels in order to } \\
\text { facilitate trade and promote } \\
\text { economic development in the } \\
\text { vicinity of port complexes. }\end{array}$ & $\begin{array}{l}\text { BIMSTEC will actively } \\
\text { promote the development } \\
\text { of new ports in the } \\
\text { Member States and } \\
\text { expansion of existing harbor } \\
\text { infrastructure designed to } \\
\text { increase the capacity of } \\
\text { the region's ports to handle } \\
\text { the anticipated growth in } \\
\text { container traffic. }\end{array}$ & $\begin{array}{l}\text { Karnafully Container Terminal in } \\
\text { Chittagong (BAN) } \\
\text { New container port at Diamond Harbor } \\
\text { (IND) } \\
\text { Construction of East Terminal at } \\
\text { Colombo (SRI) } \\
\text { Construction of West Terminal at } \\
\text { Colombo (SRI) } \\
\text { Phase III at Laem Chabang (THA) } \\
\text { Coastal terminal at Laem Chabang (THA) } \\
\text { Rail terminal at Laem Chabang (THA) }\end{array}$ \\
\hline $\begin{array}{l}\text { Container } \\
\text { Handling in the } \\
\text { Bay of Bengal }\end{array}$ & $\begin{array}{l}\text { BIMSTEC recognizes the } \\
\text { importance of container } \\
\text { shipping to the Member States } \\
\text { and the need for ports to } \\
\text { continue investing in modern } \\
\text { container handling equipment } \\
\text { to ensure raising terminal } \\
\text { performance to help support } \\
\text { the enabling environment for } \\
\text { rapid economic development. }\end{array}$ & $\begin{array}{l}\text { BIMSTEC will encourage } \\
\text { the port sector to invest } \\
\text { in additional container } \\
\text { handling equipment, } \\
\text { commensurate with } \\
\text { demand and the need to } \\
\text { raise handling performance } \\
\text { to be compatible with world } \\
\text { "best practice" standards. }\end{array}$ & $\begin{array}{l}\text { Additional harbor cranes at Kolkata } \\
\text { (IND) } \\
\text { New port facilities at Thilawa (MYA) }\end{array}$ \\
\hline
\end{tabular}

BAN = Bangladesh, BIMSTEC $=$ Bay of Bengal Initiative for Multi-Sectoral Technical and Economic Cooperation, IND = India, MYA = Myanmar, NEP = Nepal, SRI = Sri Lanka, THA = Thailand .

Source: Asian Development Bank. 


\section{Table 6: Aviation: Policy and Strategy Linkages of Priority Projects}

\begin{tabular}{|c|c|c|c|}
\hline Issue & Policy & Strategy & Project \\
\hline $\begin{array}{l}\text { Expansion of } \\
\text { Airport Capacity }\end{array}$ & $\begin{array}{l}\text { BIMSTEC supports the need } \\
\text { to upgrade and expand airport } \\
\text { infrastructure in the Member } \\
\text { States to meet the growing regional } \\
\text { demand for air travel, with its } \\
\text { ability to help promote economic } \\
\text { development and social progress in } \\
\text { the region. }\end{array}$ & $\begin{array}{l}\text { BIMSTEC will promote } \\
\text { the demand-based } \\
\text { development of airport } \\
\text { facilities in the Member } \\
\text { States by encouraging their } \\
\text { prioritization in national } \\
\text { plans and in discussions with } \\
\text { member governments and } \\
\text { international donor agencies. }\end{array}$ & $\begin{array}{l}\text { Upgrading of runway at Dhaka } \\
\text { Airport (BAN) } \\
\text { Development of facilities at Paro } \\
\text { (BHU) } \\
\text { Upgrading of Yangon Airport } \\
\text { (MYA) } \\
\text { Major development of } \\
\text { Kathmandu Airport (NEP) } \\
\text { Phase II development of } \\
\text { Bandaranaike International } \\
\text { Airport at Colombo (SRI) } \\
\text { Major development of } \\
\text { Suvarnabhumi Airport (THA) }\end{array}$ \\
\hline $\begin{array}{l}\text { Development of } \\
\text { Freight Services } \\
\text { and Facilities }\end{array}$ & $\begin{array}{l}\text { BIMSTEC recognizes the need for } \\
\text { more modern air cargo handling } \\
\text { and equipment at the region's main } \\
\text { airports to support the growing } \\
\text { demand for airfreight movements } \\
\text { arising from the region's economic } \\
\text { development and the gradual } \\
\text { transition toward the production of } \\
\text { higher-value exports requiring more } \\
\text { rapid transit. }\end{array}$ & $\begin{array}{l}\text { BIMSTEC supports the } \\
\text { need for investment in } \\
\text { cargo infrastructure and } \\
\text { equipment at major airports } \\
\text { in the Member States and will } \\
\text { encourage its development } \\
\text { prioritization wherever } \\
\text { possible. }\end{array}$ & $\begin{array}{l}\text { Expansion and development of } \\
\text { facilities at Paro (BHU) } \\
\text { Further development of Delhi } \\
\text { Airport (IND) }\end{array}$ \\
\hline $\begin{array}{l}\text { Development of } \\
\text { Support Facilities } \\
\text { for Low-Cost } \\
\text { Carrier (LCC) } \\
\text { Operations }\end{array}$ & $\begin{array}{l}\text { BIMSTEC recognizes the } \\
\text { importance of the expansion of LCC } \\
\text { operations in the region in providing } \\
\text { increased access to international air } \\
\text { travel between BIMSTEC Member } \\
\text { States, thus helping to stimulate } \\
\text { economic development and social } \\
\text { progress in the region. }\end{array}$ & $\begin{array}{l}\text { BIMSTEC will promote } \\
\text { the development of } \\
\text { infrastructure at the region's } \\
\text { main airports in a manner } \\
\text { that facilitates LCC services, } \\
\text { without compromising the } \\
\text { infrastructure needed for } \\
\text { servicing legacy carriers. }\end{array}$ & $\begin{array}{l}\text { Improved parking aprons at } \\
\text { Dhaka (BAN) }\end{array}$ \\
\hline
\end{tabular}

BAN = Bangladesh, $\mathrm{BHU}=$ Bhutan, $\mathrm{BIMSTEC}=$ Bay of Bengal Initiative for Multi-Sectoral Technical and Economic Cooperation, $I N D=$ India, $M Y A=$ Myanmar, NEP = Nepal, SRI = Sri Lanka, $T H A=$ Thailand .

Source: Asian Development Bank.

\section{Table 7: Trade Facilitation: Policy and Strategy Linkages of Priority Projects}

\begin{tabular}{|c|c|c|c|}
\hline Issue & Policy & Strategy & Project \\
\hline $\begin{array}{l}\text { Development } \\
\text { of Border } \\
\text { Infrastructure }\end{array}$ & $\begin{array}{l}\text { BIMSTEC recognizes the need to } \\
\text { develop additional infrastructure } \\
\text { at the main land borders in the } \\
\text { Member States to facilitate the } \\
\text { movement of intra-BIMSTEC } \\
\text { trade and to assist in promoting } \\
\text { economic development in those } \\
\text { border areas. }\end{array}$ & $\begin{array}{l}\text { BIMSTEC will encourage } \\
\text { the prioritization of the } \\
\text { development of border } \\
\text { infrastructure at all of the } \\
\text { main BIMSTEC land borders, } \\
\text { including their inclusion in } \\
\text { national development plans } \\
\text { and in discussions with the } \\
\text { relevant national authorities } \\
\text { and international donors. }\end{array}$ & $\begin{array}{l}\text { Developments at Benapole and } \\
\text { Burimari (BAN) } \\
\text { New ICP at Petrapole (IND) } \\
\text { New Mae Sot/Myawaddy border } \\
\text { (THA and MYA) } \\
\text { New ICP at Birgunj (NEP) }\end{array}$ \\
\hline
\end{tabular}


Table 7 continued

\begin{tabular}{|c|c|c|c|}
\hline Issue & Policy & Strategy & Project \\
\hline $\begin{array}{l}\text { Construction of } \\
\text { Inland Clearance } \\
\text { Depots (ICDs) }\end{array}$ & $\begin{array}{l}\text { BIMSTEC recognizes the need } \\
\text { for further development of } \\
\text { ICDs in order to reduce the risk } \\
\text { of increased congestion at the } \\
\text { main seaports and to facilitate } \\
\text { clearances, thus promoting } \\
\text { economic development of inland } \\
\text { seaboards. }\end{array}$ & $\begin{array}{l}\text { BIMSTEC will promote the } \\
\text { development of ICDs at } \\
\text { appropriate locations in the } \\
\text { Member States by encouraging } \\
\text { their inclusion in national } \\
\text { development plans and in } \\
\text { discussions with relevant } \\
\text { authorities and donors. }\end{array}$ & $\begin{array}{l}\text { Second rail-connected ICD in } \\
\text { Dhaka (BAN) } \\
\text { New dry port at Phuentsholing + } \\
\text { northern bypass (BHU) } \\
\text { ICD at Pasakha Industrial Estate } \\
+ \text { access road (BHU) } \\
\text { Yangon/East Dagon ICD project } \\
\text { (MYA) }\end{array}$ \\
\hline $\begin{array}{l}\text { Simplification and } \\
\text { Harmonization } \\
\text { of Import-Export } \\
\text { Documentation }\end{array}$ & $\begin{array}{l}\text { BIMSTEC recognizes the } \\
\text { need for simplification and } \\
\text { harmonization of the regional } \\
\text { trade facilitation environment in } \\
\text { order to promote intra-BIMSTEC } \\
\text { trade and consequent economic } \\
\text { development. }\end{array}$ & $\begin{array}{l}\text { BIMSTEC will encourage } \\
\text { Member States to review and } \\
\text { rationalize their documentation } \\
\text { requirements in relation to } \\
\text { import and export clearances } \\
\text { wherever possible and promote } \\
\text { the development of more } \\
\text { mutual recognition agreements } \\
\text { between Member States. }\end{array}$ & $\begin{array}{l}\text { Possible SASEC project business } \\
\text { process analysis extension }\end{array}$ \\
\hline $\begin{array}{l}\text { Further } \\
\text { Development } \\
\text { of Automated } \\
\text { systems }\end{array}$ & $\begin{array}{l}\text { BIMSTEC recognizes the need } \\
\text { to further automation in the } \\
\text { trade facilitation environment, } \\
\text { including implementation of } \\
\text { more processing applications } \\
\text { and the development of national } \\
\text { single windows, in order to } \\
\text { promote trade in the BIMSTEC } \\
\text { Member States and to realize } \\
\text { the economic development that } \\
\text { such trade can generate. }\end{array}$ & $\begin{array}{l}\text { BIMSTEC will encourage the } \\
\text { prioritization of upgrading } \\
\text { of existing IT systems within } \\
\text { national customs operations } \\
\text { and help promote the } \\
\text { establishment of national single } \\
\text { windows with the relevant } \\
\text { national organizations and } \\
\text { international donors. }\end{array}$ & $\begin{array}{l}\text { Customs IT upgrades in } \\
\text { Bangladesh, Bhutan, Myanmar, } \\
\text { and Nepal } \\
\text { Development of national single } \\
\text { windows in all countries except } \\
\text { Thailand }\end{array}$ \\
\hline
\end{tabular}

BAN = Bangladesh, $\mathrm{BHU}=$ Bhutan, $\mathrm{BIMSTEC}=$ Bay of Bengal Initiative for Multi-Sectoral Technical and Economic Cooperation, CBTA = cross-border transport agreement, ICP = integrated check post, IND = India, IT = information technology, MYA = Myanmar, NEP $=$ Nepal, SASEC $=$ South Asia Subregional Economic Cooperation, THA = Thailand.

Source: Asian Development Bank.

\section{BIMSTEC Transport Infrastructure and Logistics Action Plan 2014-2020}

The objective of the BIMSTEC Transport Infrastructure and Logistics Action Plan 2014-2020 is to provide a "road map" to enhanced regional transport development based on improved connectivity, particularly to support growth in intra-regional trade. Firstly, it is designed to highlight the key BIMSTEC program developments and their respective scheduling, tracking progress in the implementation of regional transport infrastructure and logistics projects. Secondly, it can act as a simple monitoring mechanism, so that the BIMSTEC Secretariat and/or its technical support resources can easily measure the implementation for the agreed policies and strategies on a regular basis. 
It is recognized BIMSTEC is neither a funding nor implementation agency and therefore its influence over the execution of the overall plan may be limited. Nonetheless, as a regional "pressure group" with increasing influence, BIMSTEC may be able to persuade Member States to prioritize projects which have been delayed and/or to promote the early implementation or completion of others. To be able to exert influence in the transport sector, it is important that BIMSTEC has an established plan and is able to collect relevant data to identify progress in the implementation of that plan.

The BIMSTEC Transport Infrastructure and Logistics Action Plan 2014-2020 shown in Table 8 comprises of a list of these policy and strategy indicators, together with their projected implementation timescales. This will allow the BIMSTEC Secretariat to use the plan to highlight the undertaking and completion of various projects to be able to demonstrate and publicize policy progress. The majority of these projects are scheduled for completion between 2014 and 2018, including some short-term projects capable of demonstrating the achievement of some early goals. However, it is realized with projects of this complexity and cost that some "slippage" is almost inevitable, thus the emphasis on projects expected to be completed within the plan's time frame even allowing for such slippage.

It is important to appreciate that the plan should remain a "live" document. As projects are completed, they should be replaced with other relevant projects, probably from the long list, though it is recognized that during the plan's implementation period, new projects and emphasis may arise. The plan should be seen as a rolling implementation program, thus the need for regular monitoring of projects within the plan.

The difficulties in implementing the BIMSTEC Transport Infrastructure and Logistics Plan 2014-2020 should not be underestimated. The cost of implementing the long list of BIMSTEC projects is estimated at $\$ 45$ billion $-\$ 50$ billion, of which only approximately $\$ 18$ billion, or less than $40 \%$, has been identified as having indicative funding sources. The implementation cost of the new projects on the plan's short list of priority projects is estimated to be about $\$ 15$ billion, of which approximately $\$ 8$ billion, or just over $50 \%$, has provisional allocated funding from government, donor, or private sources. Consequently, the risk of implementation delays due to funding shortfalls is still significant. In addition, some of the ongoing projects are being undertaken in stages, and indications are that sufficient funding to complete all of the phases may not have been allocated at this stage. 


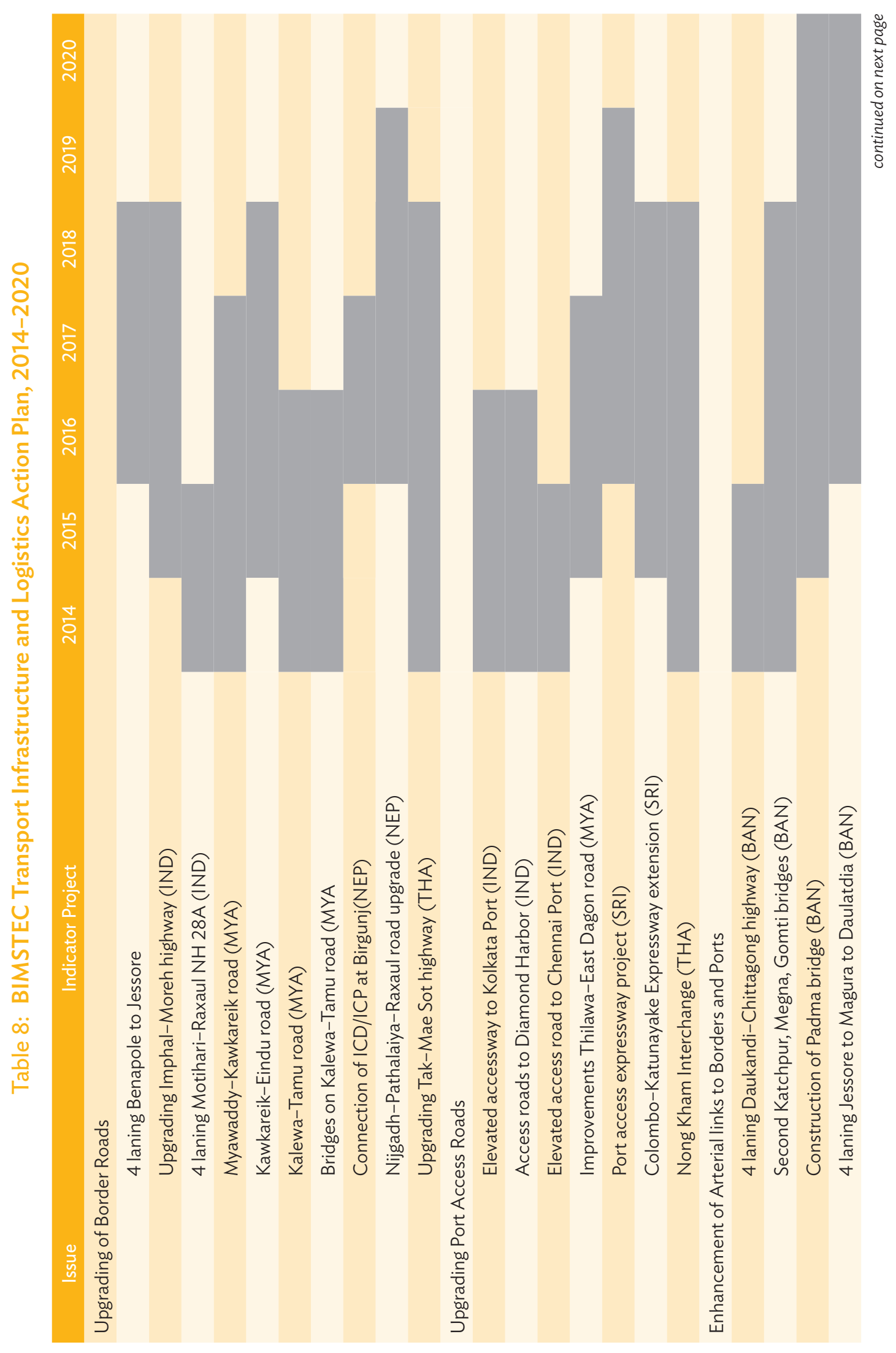




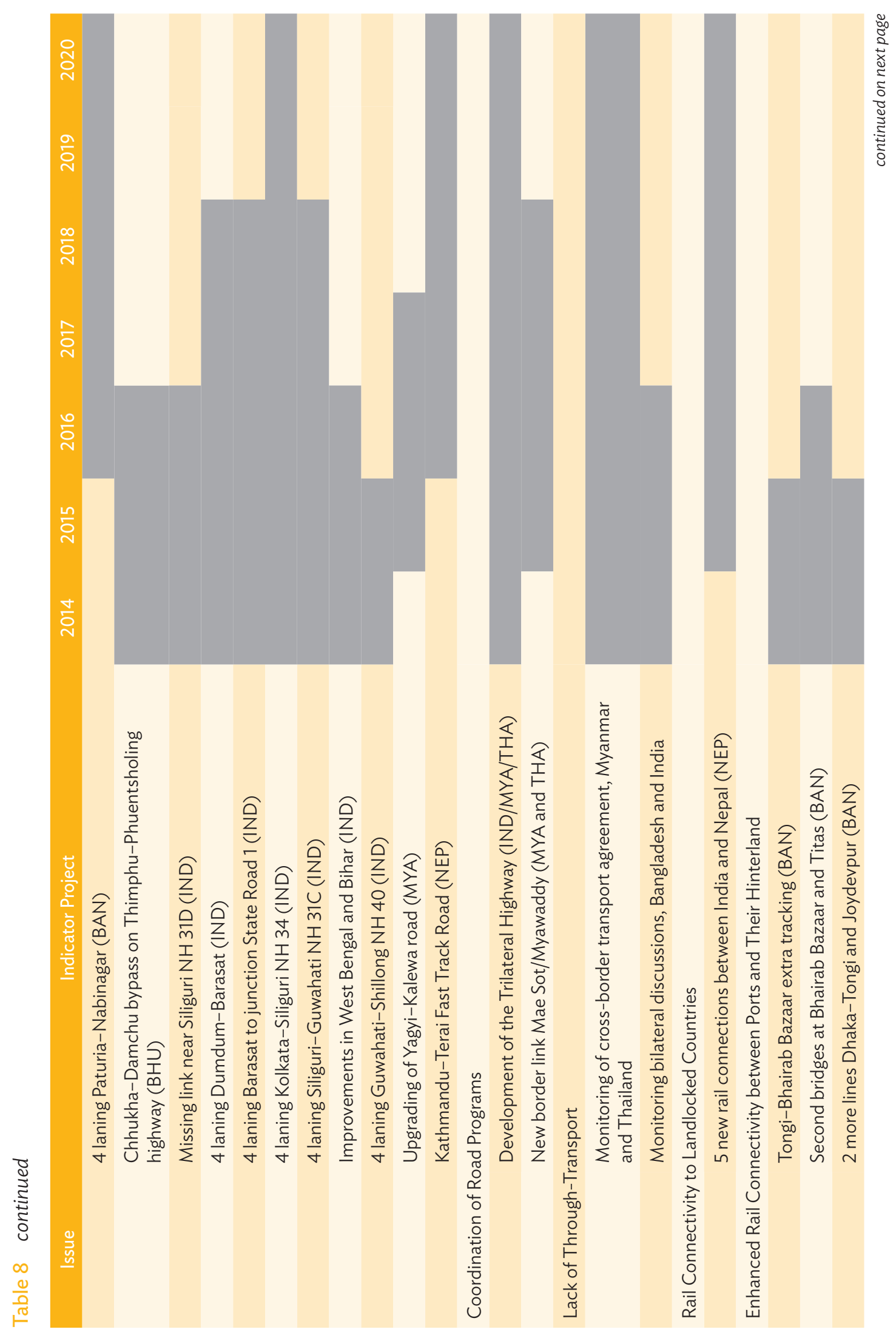




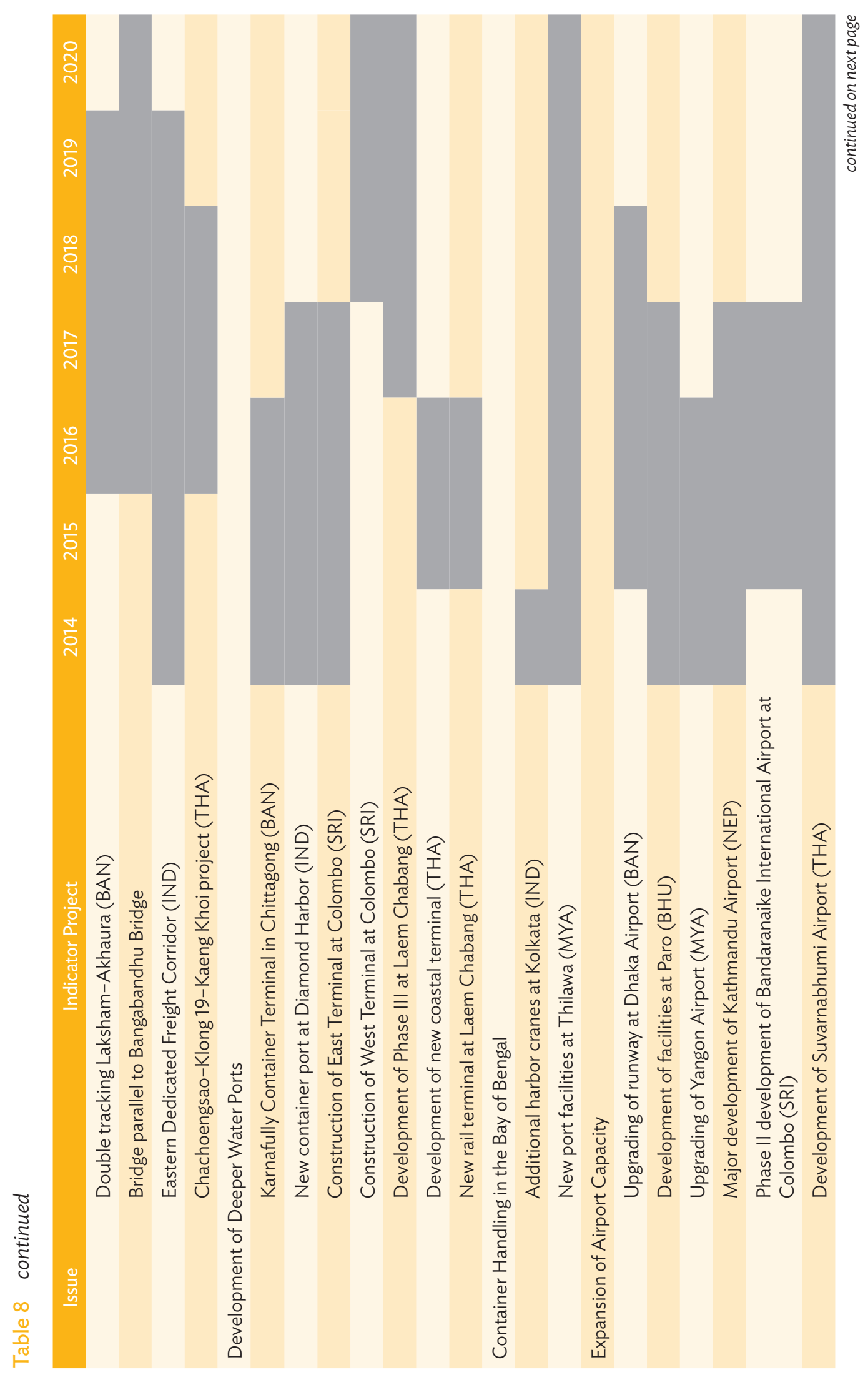




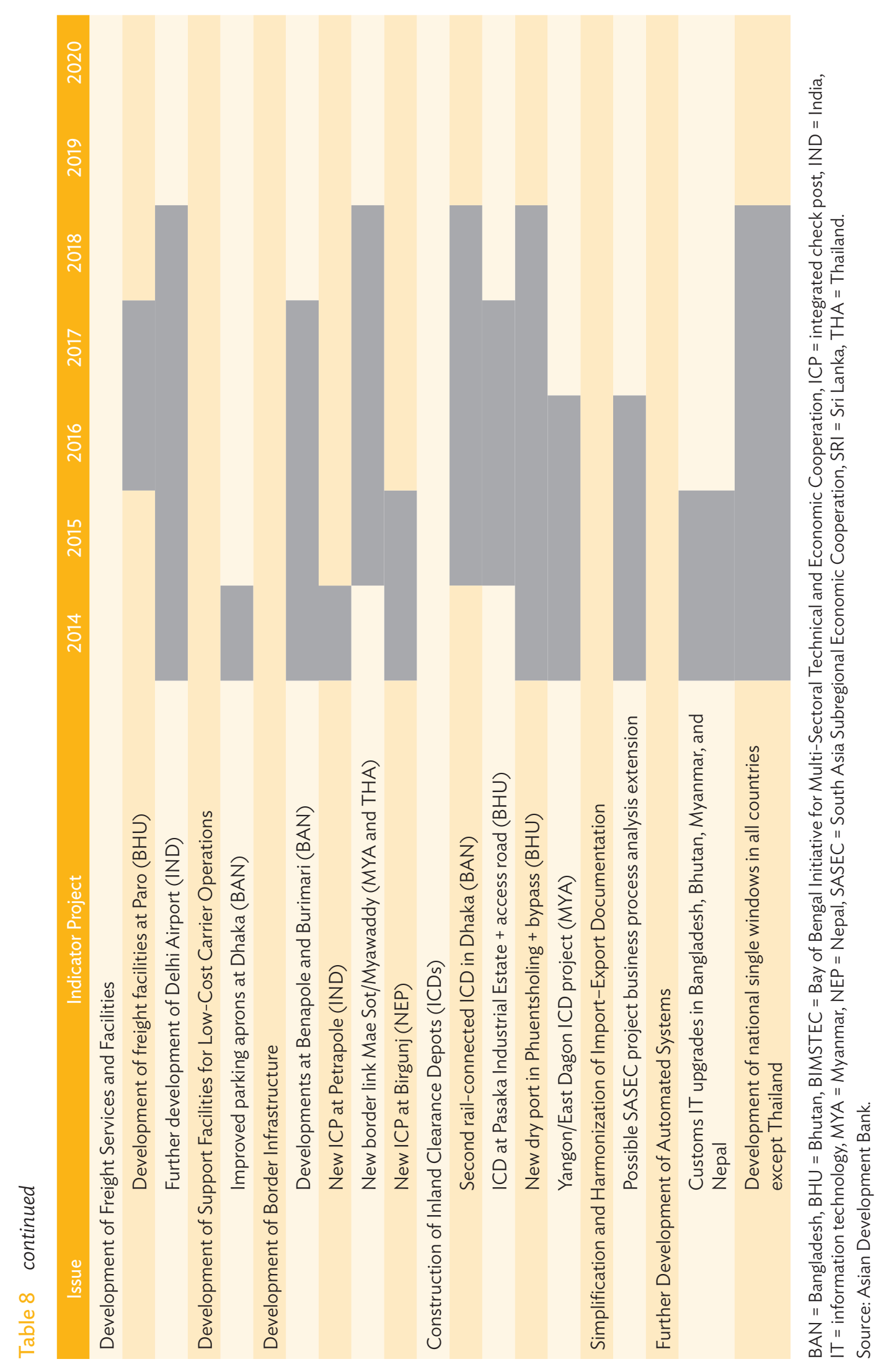




\section{Monitoring Framework}

The development of an effective monitoring framework capable of measuring progress in the implementation of the study recommendations will become critically important once those recommendations have been endorsed by BIMSTEC. As indicated, one of the caveats highlighted in the assessment of the current policies and strategies was the absence of a monitoring arrangement under the BTILS and the consequent lack of knowledge within BIMSTEC as to how both these and the action plan were progressing. The proposal is to rectify this situation by developing a simple monitoring framework to track implementation of both the updated policies and strategies and the new action plan.

The proposed framework is based on utilizing the projects as indicators for each of the policies and strategies as shown in the action plan above. This approach means that, by monitoring the progress of the individual projects within the plan, it is also possible to measure implementation of the agreed policies and strategies. This duality simplifies the monitoring processes and limits the amount of data necessary to identify progress in both areas.

The monitoring would be based on tracking the progress of each of the projects and programs within the action plan. The initial activity would be to contact relevant project owners and stakeholders to obtain basic project information in order to compile an implementation status checklist. The purposes of this step are primarily to (i) determine the present phase of implementation: namely, planning, project preparation, securing financing procurement, and construction; (ii) identify the specific remaining subphases of work to be accomplished; and (iii) to determine an appropriate time frame and duration for each of the remaining subphases of work. Essentially, this provides a more detailed analysis of the 2014-2020 action plan by breaking the various projects down into their individual development components.

The second phase would be to develop an individual time-based implementation spreadsheet for each indicator project covering the remaining subphases of work to be accomplished. A standard format for this spreadsheet could be developed for all Member States to follow, in order to standardize reporting throughout BIMSTEC, irrespective of the country or type of project. A sample of such a Microsoft Excel-based spreadsheet is shown in Appendix 2. This spreadsheet should be a "live" document designed to be updated by respective project owners on a six monthly basis. Ideally, the project milestones should also be identified in order to have a greater understanding of progress being achieved. One option could be to incorporate this into the BIMSTEC website, thus enabling BIMSTEC to publically demonstrate its ability to implement its policies, strategies, and plans.

The monitoring mechanism will need to be agreed by the appropriate body within BIMSTEC, as well as identification of the parties responsible for its application. It should be noted that tracking progress in over 60 projects spread over seven Member States will require both coordination and resources to be effective. The monitoring would be in two stages - firstly the establishment of the system, and secondly the collation of information to operationalize the monitoring process. 


\section{Institutional Framework for BTILS Implementation}

In this report, the "institutional framework" relates to the level of sector committees representing the priority sectors, and more specifically the Transport and Communication Sectoral Committee chaired by India as the lead country, plus any proposed expert working groups. The BTILS indicated that once the proposed policy framework and strategies were endorsed by the BIMSTEC policy bodies, the sector committee would decide on the activities and details of investment projects. It was further proposed that the BIMSTEC Transport and Communication Sectoral Committee be divided into two separate committees, one covering communications and the other transport and logistics. This proposal recognized both the importance of each sector and that there now remained limited synergy between the two subjects.

At the time, it was understood that, due to the different transport modes and the need for technical advice, there should be some form of technical coordination body between the lead country and the expert groups representing each transport sector. This body was required to coordinate projects and activities under the BIMSTEC transport cooperation agenda, including the action plan and implementation program. It also proposed the establishment of five expert groups representing the transport spectrum that had been addressed by the BTILS study. These groups were to be as follows:

- road development,

- railways,

- maritime transport,

- aviation, and

- transport facilitation and logistics.

Unfortunately, most of these expert groups were never formed, nor the coordinating body. The only meeting to date has been of the road expert group at the inception workshop for this study in Yangon, Myanmar, in May 2013, and this was arranged by ADB as part of that forum. The inability to establish the expert groups until 2013 could have resulted from the significant lapse time between their proposed formation and the circulation of their terms of reference in 2007 and the final endorsement of the BTILS 2 years later. It may also potentially reflect a possible lack of motivation to form such an institutional framework during a period when BIMSTEC itself has had difficulties in asserting itself as a key economic cooperation initiative in the region, particularly in the absence of a permanent secretariat. Thirdly, there may have been an underlying perception that such a structure might duplicate institutional framework committees established under the ADB Greater Mekong Subregion and SASEC initiatives or institutions such as the Association of Southeast Asian Nations (ASEAN), and/or the South Asian Association for Regional Cooperation (SAARC).

The overall conclusion was that the proposed structure of individual sector expert working groups reporting to a BIMSTEC sector committee on transport and logistics, assuming such a sector committee was ever formed, is unlikely to be sustainable. The road sector and trade facilitation appeared to be the only areas where the appropriate level of common 
interest and need for cooperation might have been sufficient to generate interest and active participation, although even this may be questionable due to the potential overlap with other subregional initiatives' existing sector bodies covering these subjects. This suggested a need to rethink the overall concept of establishing sector expert working groups.

When considering a new institutional framework, it was important to also consider the mandated role of the lead country, which under the BIMSTEC priority sector arrangements is responsible for identifying specific projects for facilitation cooperation and to function in consultation with any expert group drawn from Member States. The lead country was also required to chair and coordinate the work of the expert group and to perform the secretariat functions of that expert group, in such a way as to ensure satisfactory and successful implementation of the projects and to monitor the progress of the work. The members of the expert group were expected to be in regular contact through correspondence, including by fax and e-mail, and would meet whenever deemed necessary.

Another factor to consider is the recent establishment of the BIMSTEC Secretariat. Theoretically, the secretariat should be responsible for overall coordination of all BIMSTEC activities, including those in the transport sector. At this stage, the institutional relationship between the BIMSTEC Secretariat and the lead country of the various sector committees has yet to be clarified.

Given the problems in establishing the transport sector expert working groups, the lack of internal resources within BIMSTEC, and that the Transport Infrastructure and Logistics Action Plan 2014-2020 addresses a range of transport modes, an alternative institutional framework has been proposed. Firstly, it is suggested that instead of a number of different transport sector expert working groups, BIMSTEC should rely on the formation of a single combined BIMSTEC transport connectivity working group consisting of nominated national experts. Instead of forming expert groups for each transport sector, this working group would, in effect, be the "expert group," with the composition varying according to the particular subject being addressed, with a general meeting once annually, plus working meetings as required.

Consistent with its existing mandate, the lead country, in consultation with the BIMSTEC Secretariat, would convene the working group, and coordinate its work until such time that a decision is made by the relevant BIMSTEC body responsible for the coordination and reporting mechanisms for the working group. ADB may also be requested to provide technical assistance as required.

At any meeting, the composition of the working group should be based specifically on the nature of the particular subject(s) to be discussed, with the membership of the delegations being coordinated by the focal points to be identified by Member States and nominated to the lead country. This flexible arrangement means that all transport modes and trade facilitation can be addressed through a single identified BIMSTEC entity and the relevant national expertise can be assembled as appropriate. This approach also ensures that when ministry officials are requested to attend such meetings, there are relevant issues to be discussed and decisions made. The host country will chair the meeting with the lead country co-chairing (in cases where the host country is not the lead country). Until such time that a decision is made on the reporting mechanism for the working group, the lead 
country, in consultation with the BIMSTEC Secretary General, will report the outcomes of the work of the working group to the appropriate BIMSTEC bodies.

\section{Potential BTILS Development Theme}

As indicated earlier, BIMSTEC's role in promoting regional development in the transport sector has been limited to date, and therefore there is a need to consider new approaches designed to raise its profile, in this case within the international transport sector. One option is to develop a promotional "theme" or "vision" which could be used to raise regional awareness of BIMSTEC as a development entity and, more specifically, its role in developing the transport sector. In regional development forums, this theme can be developed using a top-down approach, but more often using a bottom-up approach based on the activities it undertakes or plans to adopt. In the case of the BIMSTEC transport sector, this theme identification process can be undertaken by examining the range of priority projects to identify elements of commonality that link them together and which would be compatible with the proposed policies and strategies.

In the context of surface transport, there are three dominant existing or potential BIMSTEC trade routes (see map):

- Route 1: Kolkata-Siliguri-Guwahati-Imphal-Moreh/Tamu-Mandalay-BagoMyawaddy/Mae Sot-Tak-Bangkok-Laem Chabang;

- $\quad$ Route 2: Kolkata-Petrapole/Benapole-Jessore-Dhaka-Chittagong; and

- Route 3: Kolkata-Raxaul/Birgunj-Kathmandu.

In the case of Route 1, the volume of international traffic varies considerably along the different sections, with the dominant flows being at the eastern and western ends. In the original BTILS, there was some discussion on potential development of BIMSTEC corridors, partly based on the earlier SAARC corridor concept. The major constraint with either transport or economic corridors is that it often tends to suggest the various sections of the corridor are equally important and that traffic travels from one end of the corridor to the other. This is not the case in relation to this trade route, where some sections are critical high-volume sections, whereas others have very low movements of trade. The concept of the project prioritization earlier enforces the view that some sections are more important than others. Traders understandably want priority investment on the transport linkages carrying the most trade, rather than the route as a whole. This particular trade route links South Asia and Southeast Asia, even if the central section consisting of the strategically important Trilateral Highway that forms the "bridgehead" remains only partly developed at this stage. If the ancillary spur connections into Bangladesh, Bhutan, and Nepal are included, of the 29 priority road developments, 14 , or almost $50 \%$, are projects either on or linked to this key trade route.

The second trade route is between Kolkata and Chittagong and consists of two main components on either side of Dhaka, both of which are handling large volumes of international and domestic trade. Unlike the first trade route, this link is busy along almost its entire length. There is as yet no connection at the eastern end into Myanmar, though 


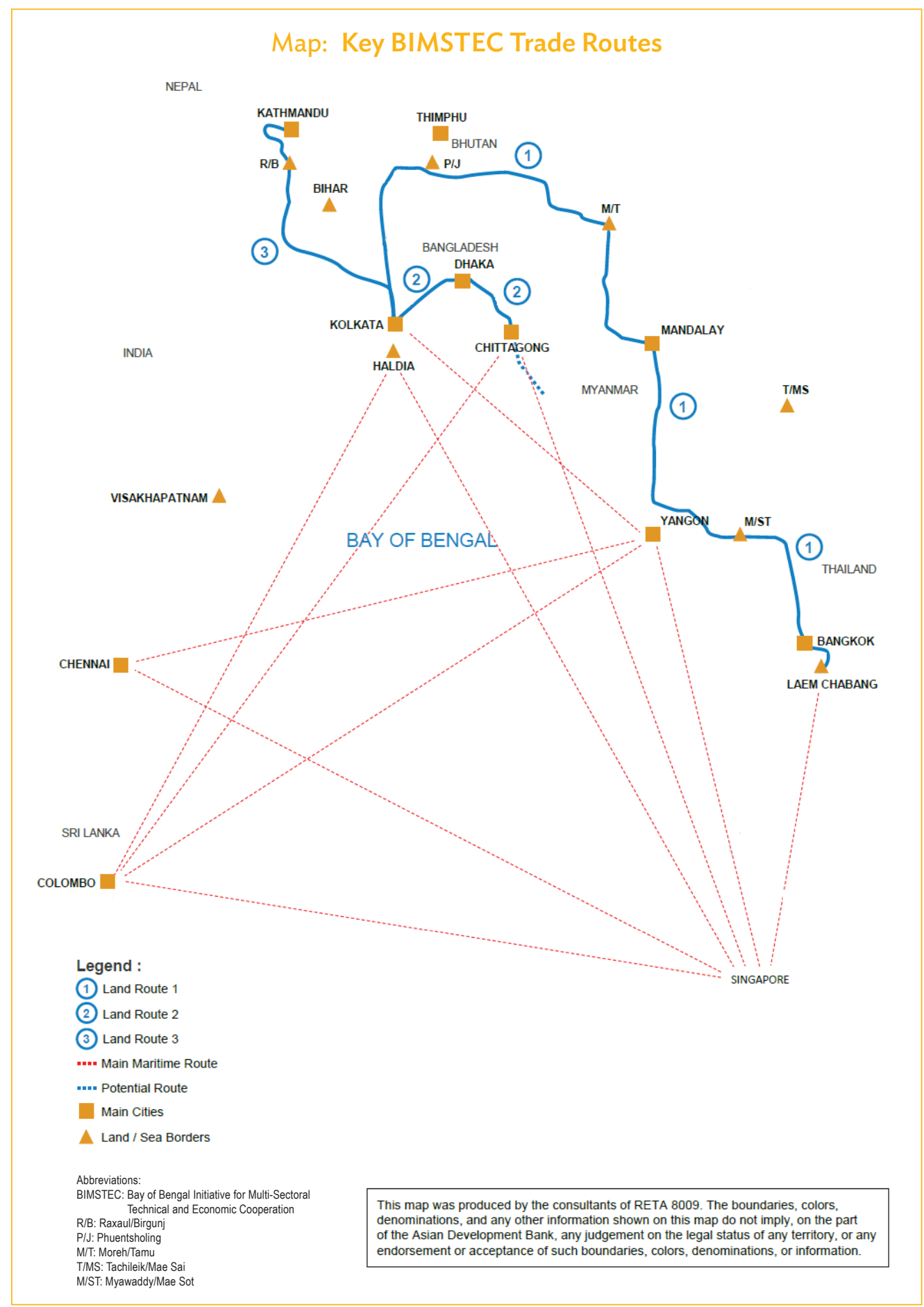


there have been bilateral discussions on establishing such a link. If this were realized, this would be a second route connection between South Asia and Southeast Asia. This southern route includes 11 priority road and rail sections.

The third trade route is between Kolkata and Nepal. However, one of the issues is that road transporters tend to use three different routings on the Indian side, though the main one is via Patna. Another issue is that, while this is one of the busiest border crossings in the BIMSTEC region in terms of tonnage throughput, this is predominantly bilateral trade with a wide range of origins or destinations on the Indian side. Nepal's third-country traffic uses the Kolkata-Raxaul road and rail links, but the bilateral traffic only tends to become more concentrated north of Patna and closer to Raxaul. There are six priority projects on this route.

The situation with the ports differs as there are hub ports, such as Colombo; major ports with a mix of mother ships and feeder ships, such as Chennai and Laem Chabang; and yet other ports serviced only by feeder ships, such as Bangkok, Chittagong, Kolkata, and Yangon. In this last case, the connectivity between South Asia and Southeast Asia tends to be mainly indirect via the hub ports, which in addition to Colombo include Singapore, and Port Klang and Tanjung Pelepas in Malaysia. There are direct or indirect sea routes between all the main BIMSTEC ports, thus helping to promote intra-BIMSTEC trade. In the case of aviation, almost all the main BIMSTEC airports are linked with each other by direct airline services with legacy carriers or LCCs, or both.

An assessment of the projects suggested that connectivity appeared to be the core common theme and this aligns with the policies and strategies which predominantly promote enhanced transport connectivity and intra-regional trade linkages. BIMSTEC is seen as the only regional development forum which specifically links South Asia and Southeast Asia by virtue of its country membership. While it has been suggested BIMSTEC could be the organization that links South Asia and Southeast Asia, in transport terms this wording suggests a dominant east-west orientation, as promoted by India's Look East and Thailand's Look West policies. However, this approach tends to devalue the importance of the north-south orientation of linkages to and from the landlocked countries and for Sri Lanka. The importance of both orientations and the need for promoting intra-regional linkages between all of the BIMSTEC members suggests "Promoting transport connectivity among BIMSTEC Member States" would be a more embracive development theme. 


\section{BIMSTEC Phase I Long List \\ of Transport Infrastructure \\ Projects and Other Relevant Ongoing Projects}

The following is the "long list" of transport infrastructure projects contained in the Updating and Enhancement of the BIMSTEC Transport and Infrastructure and Logistics Study Phase I Report agreed by the Phase I workshop held in Mae Sot, Thailand, in March 2014 and the additional ongoing projects included in the priority project screening process in the Phase II report.

Table A1.1: Road Projects

\begin{tabular}{|c|c|c|c|c|c|c|c|c|}
\hline No & Country & Road Link & No & Country & Road Link & No & Country & Road Link \\
\hline 1 & BAN & $\begin{array}{l}4 \text { laning Benapole to } \\
\text { Jessore }\end{array}$ & 25 & IND & $\begin{array}{l}4 \text { laning national } \\
\text { highway }(\mathrm{NH}) \text { from } \\
\text { Dumdum to Barasat }\end{array}$ & 49 & NEP & $\begin{array}{l}\text { Kathmandu-Hetauda } \\
\text { tunnel road }\end{array}$ \\
\hline 2 & BAN & $\begin{array}{l}4 \text { laning Jessore to } \\
\text { Magura to Daulatdia }\end{array}$ & 26 & IND & $\begin{array}{l}4 \text { laning } \mathrm{NH} \text { from } \\
\text { Barasat to junction } \\
\text { State Road } 1\end{array}$ & 50 & NEP & $\begin{array}{l}\text { Kathmandu-Terai Fast } \\
\text { Track Road }\end{array}$ \\
\hline 3 & BAN & $\begin{array}{l}\text { Construction of the } \\
\text { Padma bridge }\end{array}$ & 27 & IND & $\begin{array}{l}4 \text { laning new bypass } \\
\text { road Barasat to } \\
\text { Bongaon }\end{array}$ & 51 & NEP & $\begin{array}{l}\text { Nijgadh-Pathalaiya- } \\
\text { Raxaul road upgrade }\end{array}$ \\
\hline 4 & BAN & $\begin{array}{l}4 \text { laning of the Paturia } \\
\text { to Nabinagar section }\end{array}$ & 28 & IND & $\begin{array}{l}4 \text { laning highway link } \\
\text { near Siliguri NH 31D }\end{array}$ & 52 & NEP & $\begin{array}{l}\text { Connection road } \\
\text { between ICP/ICD }\end{array}$ \\
\hline 5 & BAN & $\begin{array}{l}4 \text { laning Akhura to } \\
\text { Dharkhar }\end{array}$ & 29 & IND & $\begin{array}{l}\text { 2-4 laning NH from } \\
\text { Imphal to Moreh }\end{array}$ & 53 & NEP & $\begin{array}{l}\text { Widening of Birgunj } \\
\text { bypass road }\end{array}$ \\
\hline 6 & BAN & $\begin{array}{l}4 \text { laning Dharkhar to } \\
\text { Mainamati }\end{array}$ & 30 & IND & $\begin{array}{l}\text { Improvements in } \\
\text { highway links in West } \\
\text { Bengal and Bihar }\end{array}$ & 54 & NEP & $\begin{array}{l}\text { Dharan-Biratnagar } \\
\text { (Nepal) road } \\
\text { expansion }\end{array}$ \\
\hline 7 & BAN & $\begin{array}{l}4 \text { laning Dharkhar to } \\
\text { Sarail }\end{array}$ & 31 & IND & $\begin{array}{l}4 \text { laning Kolkata- } \\
\text { Siliguri corridor NH34 }\end{array}$ & 55 & NEP & $\begin{array}{l}\text { Belhiya (Nepal)/ } \\
\text { Sunauli (India) upgrade }\end{array}$ \\
\hline 8 & BAN & $\begin{array}{l}4 \text { laning Tamabil to } \\
\text { Sylhet }\end{array}$ & 32 & IND & $\begin{array}{l}4 \text { laning Motihari- } \\
\text { Raxaul NH 28A }\end{array}$ & 56 & NEP & $\begin{array}{l}\text { Mungling-Narayanghat } \\
\text { upgrade }\end{array}$ \\
\hline 9 & BAN & 4 laning Sylhet to Sarail & 33 & IND & $\begin{array}{l}\text { Upgrading Panitanki- } \\
\text { Fulbari link }\end{array}$ & 57 & NEP & $\begin{array}{l}\text { Upgrading Mahendra } \\
\text { Rajmarga east-west } \\
\text { road }\end{array}$ \\
\hline 10 & BAN & $\begin{array}{l}4 \text { laning Sarail to } \\
\text { Katchpur }\end{array}$ & 34 & IND & $\begin{array}{l}\text { Upgrading of Jaigaon- } \\
\text { Changrabanda route }\end{array}$ & 58 & NEP & $\begin{array}{l}\text { Construction of } \\
\text { Makakali Bridge }\end{array}$ \\
\hline
\end{tabular}




\section{Table A1.1 continued}

\begin{tabular}{|c|c|c|c|c|c|c|c|c|}
\hline No & Country & Road Link & No & Country & Road Link & No & Country & Road Link \\
\hline 11 & BAN & $\begin{array}{l}\text { Chittagong-Gundum } \\
\text { (Bangladesh)- } \\
\text { Taungbro-Bawlibazar- } \\
\text { Kuyaktaw (Myanmar) } \\
\text { road }\end{array}$ & 35 & IND & $\begin{array}{l}4 \text { laning Siliguri- } \\
\text { Guwahati NH 31C }\end{array}$ & 59 & NEP & $\begin{array}{l}\text { Upgrading of Banepa- } \\
\text { Bardibas Highway }\end{array}$ \\
\hline 12 & BAN & $\begin{array}{l}4 \text { laning Panchagahar } \\
\text { to Ranpur }(\mathrm{NH}-5)\end{array}$ & 36 & IND & $\begin{array}{l}4 \text { laning Guwahati- } \\
\text { Shillong NH } 40\end{array}$ & 60 & NEP & $\begin{array}{l}\text { Kathmandu Valley } \\
\text { Road Improvement } \\
\text { Project }\end{array}$ \\
\hline 13 & BAN & $\begin{array}{l}4 \text { laning Burimari to } \\
\text { Lalmonirhat to Ranpur }\end{array}$ & 37 & IND & $\begin{array}{l}\text { Upgrading Shillong - } \\
\text { Dawki NH } 40\end{array}$ & 61 & SRI & $\begin{array}{l}\text { Extension of Colombo- } \\
\text { Katunaya Expressway }\end{array}$ \\
\hline 14 & BAN & $\begin{array}{l}4 \text { laning Ranpur to } \\
\text { Hatikamrul }(\mathrm{NH}-5)\end{array}$ & 38 & IND & $\begin{array}{l}\text { Upgrading Guwahati- } \\
\text { Imphal road }\end{array}$ & 62 & SRI & $\begin{array}{l}\text { Elevated port } \\
\text { expressway project }\end{array}$ \\
\hline 15 & BAN & $\begin{array}{l}\text { Construction Dhaka- } \\
\text { Chittagong Expressway }\end{array}$ & 39 & MYA & $\begin{array}{l}\text { Construction of Bago } \\
\text { NR } 1 \text { bypass road }\end{array}$ & 63 & SRI & $\begin{array}{l}\text { Phase III of the Outer } \\
\text { Circular Highway }\end{array}$ \\
\hline 16 & BAN & $\begin{array}{l}4 \text { laning Jhenaidah- } \\
\text { Jessore-Khulna- } \\
\text { Mongla highway }\end{array}$ & 40 & MYA & $\begin{array}{l}\text { Improvements to } \\
\text { Eindu-Thaton road }\end{array}$ & 64 & SRI & $\begin{array}{l}\text { Colombo elevated } \\
\text { expressway programs }\end{array}$ \\
\hline 17 & BAN & $\begin{array}{l}4 \text { laning Daudkandi- } \\
\text { Chittagong highway }\end{array}$ & 41 & MYA & $\begin{array}{l}\text { Upgrading of the } \\
\text { Thaton-Payagyi road }\end{array}$ & 65 & SRI & $\begin{array}{l}\text { Northern Highway } \\
\text { phases 1-4 }\end{array}$ \\
\hline 18 & BAN & $\begin{array}{l}\text { Second Katchpur, } \\
\text { Megna, Gomti bridges }\end{array}$ & 42 & MYA & $\begin{array}{l}\text { New border link Mae } \\
\text { Sot/Myawaddy }\end{array}$ & 66 & SRI & $\begin{array}{l}\text { Stage } 4 \text { of Southern } \\
\text { Expressway }\end{array}$ \\
\hline 19 & $\mathrm{BHU}$ & $\begin{array}{l}2 \text { laning Samrang- } \\
\text { Jomotsangkha road }\end{array}$ & 43 & MYA & $\begin{array}{l}\text { Improvement of } \\
\text { Thilawa-East Dagon } \\
\text { road }\end{array}$ & 67 & THA & $\begin{array}{l}4 \text { laning of the Tak- } \\
\text { Mae Sot highway }\end{array}$ \\
\hline 20 & $\mathrm{BHU}$ & $\begin{array}{l}2 \text { laning northern } \\
\text { bypass in } \\
\text { Phuentsholing }\end{array}$ & 44 & MYA & $\begin{array}{l}\mathrm{NH} 2 \text { between East } \\
\text { Dagon and } \mathrm{NH} 1\end{array}$ & 68 & THA & $\begin{array}{l}\text { Mae Sot/Myawaddy } \\
\text { border crossing }\end{array}$ \\
\hline 21 & $\mathrm{BHU}$ & $\begin{array}{l}\text { Chhukha-Damchu } \\
\text { bypass on Thimphu- } \\
\text { Phuentsholing Highway }\end{array}$ & 45 & MYA & $\begin{array}{l}\text { Yagyi-Kalewa road } \\
\text { improvement project }\end{array}$ & 69 & THA & $\begin{array}{l}\text { Bangkok- } \\
\text { Kanchanaburi } \\
\text { motorway }\end{array}$ \\
\hline 22 & $\mathrm{BHU}$ & $\begin{array}{l}2 \text { laning northern East- } \\
\text { West and North-South } \\
\text { highways }\end{array}$ & 46 & MYA & $\begin{array}{l}\text { New bridges on the } \\
\text { Kalewa-Tamu road }\end{array}$ & 70 & THA & $\begin{array}{l}\text { Kanchanaburi/Ban Phu } \\
\text { Nam Ron link }\end{array}$ \\
\hline 23 & IND & $\begin{array}{l}\text { Elevated road to } \\
\text { Kolkata Port }\end{array}$ & 47 & MYA & $\begin{array}{l}\text { Construction of } \\
\text { Myawaddy-Kawkareik } \\
\text { road }\end{array}$ & 71 & THA & $\begin{array}{l}\text { Nong Kham } \\
\text { Interchange }\end{array}$ \\
\hline 24 & IND & $\begin{array}{l}4 \text { laning access roads } \\
\text { to Diamond Harbor }\end{array}$ & 48 & MYA & $\begin{array}{l}\text { Construction of } \\
\text { Kawkareik-Eindu road }\end{array}$ & & & \\
\hline
\end{tabular}


Table A1.2: Railway Projects

\begin{tabular}{|c|c|c|c|c|c|c|c|c|}
\hline No & Country & Rail Link & No & Country & Rail Link & No & Country & Rail Link \\
\hline 1 & BAN & $\begin{array}{l}\text { Rail link from Bhanga } \\
\text { to Mawa }\end{array}$ & 13 & BAN & $\begin{array}{l}\text { Tongi-Bhairab Bazaar } \\
\text { extra tracking }\end{array}$ & 24 & MYA & $\begin{array}{l}\text { Upgrade of Yangon- } \\
\text { Mandalay main line }\end{array}$ \\
\hline 2 & BAN & $\begin{array}{l}\text { Rail link from Mawa to } \\
\text { Dhaka }\end{array}$ & 14 & BAN & $\begin{array}{l}\text { Kulaura-Shahbazpur } \\
\text { rail link }\end{array}$ & 25 & MYA & $\begin{array}{l}\text { Upgrading of track } \\
\text { between Bago and } \\
\text { Dawei }\end{array}$ \\
\hline 3 & BAN & $\begin{array}{l}\text { Bhanga-Narai-Jessore } \\
\text { broad gauge line }\end{array}$ & 15 & BAN & $\begin{array}{l}\text { Second bridges at } \\
\text { Bhairab Bazaar and } \\
\text { Titas }\end{array}$ & 26 & MYA & $\begin{array}{l}\text { Construction of Kalay- } \\
\text { Tamu line }\end{array}$ \\
\hline 4 & BAN & $\begin{array}{l}\text { Second rail/road bridge } \\
\text { at Kalurhat }\end{array}$ & 16 & BAN & $\begin{array}{l}2 \text { more lines Dhaka- } \\
\text { Tongi and Tongi- } \\
\text { Joydevpur }\end{array}$ & 27 & NEP & $\begin{array}{l}5 \text { new rail links with } \\
\text { India }\end{array}$ \\
\hline 5 & BAN & $\begin{array}{l}\text { Double tracking } \\
\text { Laksham-Akhaura link }\end{array}$ & 17 & IND & $\begin{array}{l}\text { New line from } \\
\text { Maynaguri to } \\
\text { Chengrabanda }\end{array}$ & 28 & SRI & $\begin{array}{l}\text { Phase } 2 \text { coastal railway } \\
\text { from Matara }\end{array}$ \\
\hline 6 & BAN & $\begin{array}{l}\text { New line from Bogra to } \\
\text { Sirajganj }\end{array}$ & 18 & IND & $\begin{array}{l}\text { New from Jibiram to } \\
\text { Imphal in Manipur }\end{array}$ & 29 & SRI & $\begin{array}{l}\text { Improving rail } \\
\text { connectivity to three } \\
\text { ports }\end{array}$ \\
\hline 7 & BAN & $\begin{array}{l}\text { Bridge parallel to } \\
\text { Bangabandhu Bridge }\end{array}$ & 19 & IND & $\begin{array}{l}\text { New line from Dimapur } \\
\text { to Kohima }\end{array}$ & 30 & SRI & $\begin{array}{l}\text { Double tracking } \\
\text { Colombo Port line }\end{array}$ \\
\hline 8 & BAN & $\begin{array}{l}\text { Double tracking Khulna } \\
\text { to Parbutipur }\end{array}$ & 20 & IND & $\begin{array}{l}\text { Eastern Dedicated } \\
\text { Freight Corridor }\end{array}$ & 31 & SRI & $\begin{array}{l}\text { Upgrading Trincomalee } \\
\text { line }\end{array}$ \\
\hline 9 & BAN & $\begin{array}{l}\text { Dohazari- Myanmar } \\
\text { railway link }\end{array}$ & 21 & IND & $\begin{array}{l}\text { New line Bhairabi- } \\
\text { Sairang }\end{array}$ & 32 & THA & $\begin{array}{l}\text { Infrastructure } \\
\text { rehabilitation }\end{array}$ \\
\hline 10 & BAN & $\begin{array}{l}\text { Construction of } \\
\text { Khulna-Mongla Port } \\
\text { railway }\end{array}$ & 22 & IND & $\begin{array}{l}\text { New line Dimapur- } \\
\text { Tizit }\end{array}$ & 33 & THA & $\begin{array}{l}\text { Chachoengsao-Klong } \\
\text { 19-Kaeng Khoi project }\end{array}$ \\
\hline 11 & BAN & $\begin{array}{l}\text { Darshana-Serajganj } \\
\text { upgrade and signaling }\end{array}$ & 23 & IND & $\begin{array}{l}\text { Double tracking New } \\
\text { Bongaigaon-Kamkhya }\end{array}$ & 34 & THA & $\begin{array}{l}\text { Study of Laem } \\
\text { Chabang-Dawei link }\end{array}$ \\
\hline 12 & BAN & $\begin{array}{l}\text { Bridge parallel to } \\
\text { Bangabandhu Bridge }\end{array}$ & & & & & & \\
\hline
\end{tabular}

BAN = Bangladesh, IND = India, MYA = Myanmar, NEP = Nepal, SRI = Sri Lanka, THA = Thailand.

Source: Asian Development Bank.

\section{Table A1.3: Maritime Projects}

\begin{tabular}{|c|c|c|c|c|c|c|c|c|}
\hline No & Country & Port & No & Country & Port & No & Country & Port \\
\hline 1 & BAN & $\begin{array}{l}\text { Karnafully Container } \\
\text { Terminal at Chittagong }\end{array}$ & 9 & IND & $\begin{array}{l}\text { Additional harbor } \\
\text { cranes at Kolkata }\end{array}$ & 17 & SRI & $\begin{array}{l}\text { Construction of West } \\
\text { Terminal. }\end{array}$ \\
\hline 2 & BAN & $\begin{array}{l}\text { Construction of Laldia } \\
\text { bulk terminal }\end{array}$ & 10 & IND & $\begin{array}{l}\text { Elevated expressway } \\
\text { into Chennai Port }\end{array}$ & 18 & SRI & $\begin{array}{l}\text { Phase II of } \\
\text { Hambantota Port }\end{array}$ \\
\hline 3 & BAN & $\begin{array}{l}\text { Container equipment } \\
\text { for New Mooring } \\
\text { Container Terminal }\end{array}$ & 11 & IND & $\begin{array}{l}\text { Chennai-Ennore Port } \\
\text { Connectivity Project }\end{array}$ & 19 & THA & $\begin{array}{l}\text { Development of new } \\
\text { coastal terminal }\end{array}$ \\
\hline 4 & BAN & $\begin{array}{l}\text { Deep sea port at } \\
\text { Sonadia Island }\end{array}$ & 12 & MYA & $\begin{array}{l}\text { New port facilities } \\
\text { at Thilawa special } \\
\text { economic zone }\end{array}$ & 20 & THA & $\begin{array}{l}\text { Development of new } \\
\text { rail terminal }\end{array}$ \\
\hline
\end{tabular}




\section{Table A1.3 continued}

\begin{tabular}{|c|c|c|c|c|c|c|c|c|}
\hline No & Country & Port & No & Country & Port & No & Country & Port \\
\hline 5 & BAN & $\begin{array}{l}\text { Multipurpose berth at } \\
\text { Mongla }\end{array}$ & 13 & MYA & $\begin{array}{l}\text { Development of new } \\
\text { port at Dawei }\end{array}$ & 21 & THA & $\begin{array}{l}\text { Development of Phase } \\
\text { III at Laem Chabang }\end{array}$ \\
\hline 6 & IND & $\begin{array}{l}\text { New container port at } \\
\text { Diamond Harbor }\end{array}$ & 14 & MYA & $\begin{array}{l}\text { Deep sea port at } \\
\text { Kyaukphyu }\end{array}$ & 22 & THA & $\begin{array}{l}\text { Development of Thai } \\
\text { land bridge }\end{array}$ \\
\hline 7 & IND & $\begin{array}{l}\text { Development of Haldia } \\
\text { II Dock Complex }\end{array}$ & 15 & SRI & $\begin{array}{l}\text { Construction of South } \\
\text { Terminal }\end{array}$ & & & \\
\hline 8 & IND & Sagar Island complex & 16 & SRI & $\begin{array}{l}\text { Extension of East } \\
\text { Terminal }\end{array}$ & & & \\
\hline
\end{tabular}

BAN = Bangladesh, IND = India, MYA = Myanmar, SRI = Sri Lanka, $\mathrm{THA}=$ Thailand .

Source: Asian Development Bank.

Table A1.4: Inland Waterway Projects

\begin{tabular}{|c|c|c|c|c|c|c|c|c|}
\hline No & Country & Project & No & Country & Project & No & Country & Project \\
\hline 1 & IND & $\begin{array}{l}\text { Kaladan project } \\
\text { connecting Kolkata } \\
\text { with its northeastern } \\
\text { states via Myanmar }\end{array}$ & 2 & MYA & Kaladan River Project & 3 & MYA & $\begin{array}{l}\text { Construction of six } \\
\text { new terminals }\end{array}$ \\
\hline
\end{tabular}

IND = India, MYA = Myanmar.

Source: Asian Development Bank.

\section{Table A1.5: Aviation Projects}

\begin{tabular}{|c|c|c|c|c|c|c|c|c|}
\hline No & Country & Port & No & Country & Port & No & Country & Port \\
\hline 1 & BAN & $\begin{array}{l}\text { New terminal at Dhaka } \\
\text { Airport }\end{array}$ & 8 & IND & $\begin{array}{l}\text { Further development } \\
\text { of Delhi Airport }\end{array}$ & 15 & NEP & $\begin{array}{l}\text { Major development of } \\
\text { Kathmandu Airport }\end{array}$ \\
\hline 2 & BAN & $\begin{array}{l}\text { Second runway at } \\
\text { Dhaka Airport }\end{array}$ & 9 & IND & $\begin{array}{l}\text { New greenfield airport } \\
\text { at Chennai }\end{array}$ & 16 & NEP & $\begin{array}{l}\text { Development of } \\
\text { second international } \\
\text { airport }\end{array}$ \\
\hline 3 & BAN & $\begin{array}{l}\text { Upgrading of runway at } \\
\text { Dhaka Airport }\end{array}$ & 10 & MYA & $\begin{array}{l}\text { New Hanthawaddy } \\
\text { International Airport }\end{array}$ & 17 & SRI & $\begin{array}{l}\text { Phase II development } \\
\text { of Bandaranaike } \\
\text { International Airport }\end{array}$ \\
\hline 4 & BAN & $\begin{array}{l}\text { Improvement of } \\
\text { parking aprons at } \\
\text { Dhaka Airport }\end{array}$ & 11 & MYA & $\begin{array}{l}\text { Upgrading of Yangon } \\
\text { Airport }\end{array}$ & 18 & SRI & $\begin{array}{l}\text { Modifications at } \\
\text { Mattala Airport }\end{array}$ \\
\hline 5 & BAN & $\begin{array}{l}\text { Redevelopment of } \\
\text { Sylhet Airport }\end{array}$ & 12 & MYA & $\begin{array}{l}\text { Upgrading of Mandalay } \\
\text { Airport }\end{array}$ & 19 & SRI & $\begin{array}{l}\text { Expansion of Mattala } \\
\text { Airport }\end{array}$ \\
\hline 6 & $\mathrm{BHU}$ & $\begin{array}{l}\text { Expansion and } \\
\text { development of Paro } \\
\text { Airport }\end{array}$ & 13 & MYA & $\begin{array}{l}\text { Upgrading of Nay Pyi } \\
\text { Taw Airport }\end{array}$ & 20 & THA & $\begin{array}{l}\text { Major development of } \\
\text { Suvarnabhumi Airport }\end{array}$ \\
\hline 7 & $\mathrm{BHU}$ & $\begin{array}{l}\text { New airport at } \\
\text { Gelephug }\end{array}$ & 14 & NEP & $\begin{array}{l}\text { Initial development of } \\
\text { Kathmandu Airport }\end{array}$ & 21 & THA & $\begin{array}{l}\text { Development of Mae } \\
\text { Sot Airport }\end{array}$ \\
\hline
\end{tabular}

BAN = Bangladesh, $\mathrm{BHU}=$ Bhutan, IND = India, MYA = Myanmar, NEP = Nepal, SRI = Sri Lanka, THA = Thailand .

Source: Asian Development Bank. 
Table A1.6: Trade Facilitation Projects

\begin{tabular}{|c|c|c|c|c|c|c|c|c|}
\hline No & Country & Project & No & Country & Project & No & Country & Project \\
\hline 1 & BAN & $\begin{array}{l}\text { Second rail connected } \\
\text { ICD in Dhaka }\end{array}$ & 6 & IND & ICP at Jaigoan & 11 & NEP & ICP at Birgunj \\
\hline 2 & BAN & $\begin{array}{l}\text { Developments at } \\
\text { Benapole and Burimari }\end{array}$ & 7 & IND & ICP at Petrapole & 12 & NEP & $\begin{array}{l}\text { ICP at three other } \\
\text { borders }\end{array}$ \\
\hline 3 & BAN & Bhomra ICD & 8 & MYA & $\begin{array}{l}\text { Kanchanaburi/Baan } \\
\text { Phu Nam Ron border } \\
\text { crossing }\end{array}$ & 13 & SRI & $\begin{array}{l}\text { Cargo village at } \\
\text { Peliyagoda }\end{array}$ \\
\hline 4 & $\mathrm{BHU}$ & $\begin{array}{l}\text { New dry port at } \\
\text { Phuentsholing }\end{array}$ & 9 & MYA & $\begin{array}{l}\text { Upgrade border } \\
\text { crossing at Tachileik }\end{array}$ & & & \\
\hline 5 & $\mathrm{BHU}$ & $\begin{array}{l}\text { ICD at Pasakha } \\
\text { Industrial Estate and } \\
\text { access road }\end{array}$ & 10 & MYA & $\begin{array}{l}\text { Yangon/East Dagon } \\
\text { ICD }\end{array}$ & & & \\
\hline
\end{tabular}

BAN = Bangladesh, $\mathrm{BHU}=$ Bhutan, $I C D=$ inland clearance depot, ICP = integrated check post, IND = India, MYA = Myanmar, $\mathrm{NEP}=$ Nepal, SRI = Sri Lanka .

Source: Asian Development Bank. 


\section{APPENDIX 2 \\ Sample Monitoring Framework}

Below is an example of a monitoring framework based on the application of a simplified time-based implementation spreadsheet for each BIMSTEC Transport Infrastructure and Logistics Study indicator project covering the various subphases of work to be accomplished. The objective is to indicate visually the progress of a transport infrastructure project from its planning through to its commissioning.

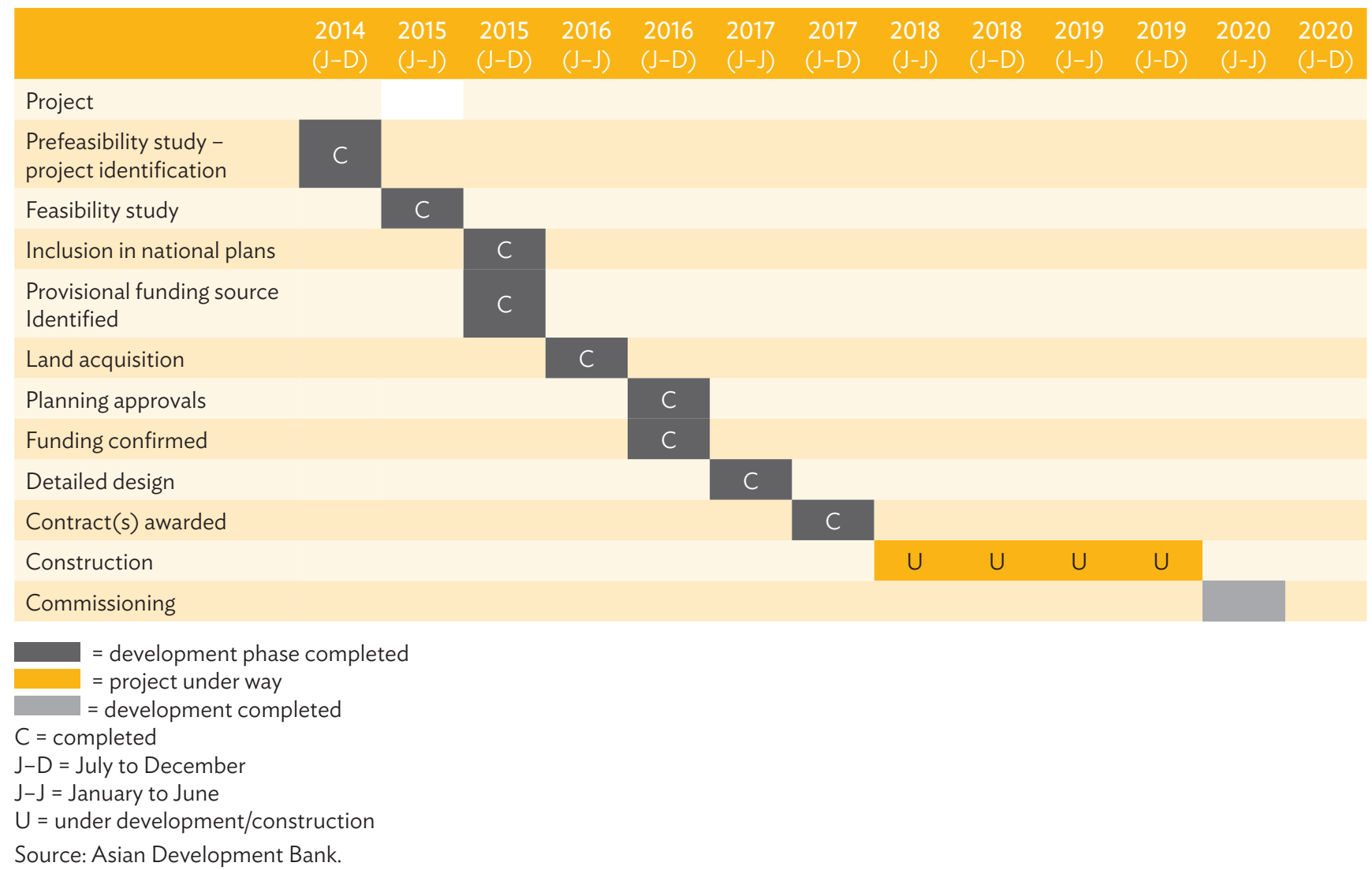




\section{Updating and Enhancement of the BIMSTEC Transport Infrastructure and Logistics Study}

One of the key aims of the Bay of Bengal Initiative for Multi-Sectoral Technical and Economic Cooperation (BIMSTEC) is to create an enabling environment for rapid economic development through identification and implementation of specific cooperation projects in identified sectors including infrastructure and transportation. BIMSTEC Transport Infrastructure and Logistics Study (BTILS) is the first major initiative undertaken by BIMSTEC with ADB's support to map the existing transport infrastructure in the region and also identify various missing links. This study was undertaken in two stages. Phase I profiles the transport and logistics environment both regionally and nationally, identifying the planned multimodal infrastructure developments designed to enhance regional connectivity. Phase II identifies key BIMSTEC transport policies and strategies for the second half of the decade. The results of both stages are combined in this Final Report.

\section{About the Asian Development Bank}

ADB is committed to achieving a prosperous, inclusive, resilient, and sustainable Asia and the Pacific, while sustaining its efforts to eradicate extreme poverty. Established in 1966, it is owned by 67 members48 from the region. Its main instruments for helping its developing member countries are policy dialogue, loans, equity investments, guarantees, grants, and technical assistance.

\section{About the Bay of Bengal Initiative for Multi-Sectoral Technical and Economic Cooperation}

The Bay of Bengal Initiative for Multi-Sectoral Technical and Economic Cooperation (BIMSTEC) was established as a regional grouping in June 1997 with the Bangkok Declaration. Its seven country membership comprises Bangladesh, Bhutan, India, Myanmar, Nepal, Sri Lanka, and Thailand. The objective of BIMSTEC is to accelerate economic growth and social progress in the region through joint endeavors.

Based in Dhaka, Bangladesh, the Permanent Secretariat of BIMSTEC is facilitating overall coordination and follow-up of approved agenda of BIMSTEC. 